\title{
DEL HURTO DE HALLAZGO AL EXPOLIO DE YACIMIENTOS ARQUEOLÓGICOS. ¿UNA OPORTUNIDAD PERDIDA?*
}

\author{
Patricia Faraldo Cabana**
}

Resumen: En este trabajo se analizan los problemas que suscita el tratamiento penal del apoderamiento de bienes encontrados en yacimientos arqueológicos por parte del descubridor. El objetivo es valorar qué aporta el nuevo delito de expolio, introducido por la reforma de 2015, a la hora de afrontar esos problemas. El estudio tiene en cuenta la larga tradición de incardinación de esta conducta entre los delitos contra el patrimonio y los problemas concursales que se plantean con los delitos de daños sobre el patrimonio histórico.

Recibido: diciembre 2019. Aceptado: julio 2020

* Este trabajo se escribe en el marco de la Acción de dinamización Red de Excelencia sobre "Consecuencias de la Gran Recesión de 2008 en el Derecho penal económico: oportunidad y desafío" (DER2017-90667-REDT); del proyecto "Política criminal y reforma penal en una sociedad en transformación" (DER2017-82390-R), del Ministerio de Economía y Competitividad; y de la Ayuda para la consolidación y estructuración de unidades de investigación competitivas del Sistema universitario de Galicia, modalidad de grupos de referencia competitiva (ED431C 2019/18), de la Consellería de Cultura, Educación y Ordenación Universitaria de la Xunta de Galicia.

** Catedrática de Derecho Penal. ORCID ID: 0000-0001-7420-3749

Facultad de Derecho, Universidade da Coruña, Campus de Elviña, 15071, A Coruña. Email: patricia.faraldo@udc.es 
Palabras clave: expolio, hurto de hallazgo, yacimientos arqueológicos, patrimonio histórico, bienes de valor histórico, artístico, cultural o científico.

\title{
FROM THEFT OF FINDS TO ARCHAEOLOGICAL LOOTING. A LOST OPPORTUNITY?
}

\begin{abstract}
This paper analyses the problems arising from the criminal treatment of the seizure of property found at archaeological sites by the discoverer. The aim is to assess what the new offence of looting, introduced by the 2015 reform, contributes to these issues in terms of addressing these problems. The study considers the long tradition of including this conduct among offences against heritage and the concurrent problems that arise with offences of damage to historical heritage.
\end{abstract}

Keywords: looting, theft of finds, archaeological sites, historical heritage, property of historical, artistic, cultural or scientific value

\section{Introducción}

El apoderamiento de bienes encontrados en yacimientos arqueológicos ${ }^{1}$ ha recibido distintos tratamientos penales a lo largo de la historia de la codificación española. Ese tratamiento se vinculó inicialmente a la consideración de cosa perdida de los

1 En la expresión "yacimientos arqueológicos" incluyo también los paleontológicos. En la jurisprudencia se entiende pacíficamente que en el concepto de yacimiento arqueológico caben los paleontológicos. Vid. la SAP de Huesca (Sección 1 $1^{\mathrm{a}}$ ) 155/2017, de 27 de diciembre (ARP 2018\272), que condena por daños en la cueva de Chaves, consistentes en el arrasamiento y destrucción de la práctica totalidad de los niveles arqueológicos de cronología neolítica. De conformidad con el art. 40.1 de la Ley 16/1985, de 25 de junio, del Patrimonio Histórico Español (en adelante, LPHE o Ley 16/1985), "forman parte del Patrimonio Histórico Español los bienes muebles o inmuebles de carácter histórico, susceptibles de ser estudiados con metodología arqueológica, hayan sido o no extraídos y tanto si se encuentran en la superficie o en el subsuelo, en el mar territorial o en la plataforma continental. Forman parte, asimismo, de este Patrimonio los elementos geológicos y paleontológicos relacionados con la historia del hombre y sus antecedentes". 
bienes descubiertos en los yacimientos. De ser considerada una forma de hurto impropio, el hallazgo y apoderamiento del llamado tesoro oculto pasó a entenderse como una forma, también impropia, de apropiación indebida, sin que nunca llegara a cumplir la totalidad de los requisitos típicos de estos clásicos delitos contra el patrimonio. A las dudas respecto de si la conducta se aproximaba más al hurto o a la apropiación indebida se unieron las discusiones sobre la calificación de estos bienes como cosa perdida o tesoro oculto y sobre cómo proceder a la valoración del perjuicio causado. Los debates al respecto no se resolvieron en el Código Penal de 1995, en el que únicamente se mencionaban los yacimientos arqueológicos en el delito de daños contra el patrimonio histórico (art. $323 \mathrm{CP}$, en su redacción original), pero no en los delitos contra el patrimonio. Solo gracias a la insistencia de la doctrina y la Fiscalía ${ }^{2}$, en la reforma de 2015 aparece un delito de expolio entre los delitos contra el patrimonio histórico. Su previsión ha sido acogida favorablemente ${ }^{3}$, incluso por quienes entienden que no cubre lagunas de punibilidad "pues dicho

2 Vid., entre otros, GARCÍA CALDERÓN, J. M.: "La relación del patrimonio histórico con el derecho penal", en AA.VV.: La lucha contra el tráfico ilicito de bienes culturales, Madrid, 2006, pp. 77 ss.; GUISASOLA LERMA, C.: "Delitos contra el patrimonio histórico", en ÁLVAREZ GARCÍA, F. J. (Dir.): Estudio crítico sobre el Anteproyecto de reforma penal de 2012, Valencia, 2013, p. 891. Por ejemplo, se recogía en la Memoria de la Unidad de Medio Ambiente de la Fiscalía General del Estado de 2008 que "la tipificación de un específico "delito de expolio de yacimientos" aparece como conveniente a la vista de los problemas que se plantean en lo referente a la tipificación de conductas en este ámbito como constitutivas de hurto o apropiación indebida".

3 Entre otros, NÚÑEZ SÁNCHEZ, A.: "La nueva regulación penal del delito de expolio de yacimientos arqueológicos", en GUISASOLA LERMA, C. (Dir.): Expolio de bienes culturales. Instrumentos legales frente al mismo, Valencia, 2018, p. 170; OTERO GONZÁLEZ, P.: "Protección penal de los daños al patrimonio histórico (tras la reforma del Código Penal operada por la LO 1/2015)", en Anuario de la Facultad de Derecho de la Universidad Autónoma de Madrid, núm. 19, 2015, pp. 346, 348 y 366; de la misma autora: "El delito doloso de daños a bienes de valor cultural (artículo 323 CP) conforme a la LO 1/2015", en BACIGALUPO SAGGESE, S./ FEIJOO SÁNCHEZ, B./ ECHANO BASALDUA, J. I. (Coords.): Estudios de Derecho penal. Homenaje al profesor Miguel Bajo, Madrid, 2016, p. 1194. 
comportamiento ya era subsumible en otros delitos preexistentes que regulan conductas prácticamente idénticas"4. Sin embargo, como veremos, el nuevo delito no ha contribuido a hacer más eficaz la tutela penal de los bienes procedentes de yacimientos arqueológicos, en parte por la indeterminación de su ámbito de aplicación. En este artículo se analizará cómo se ha llegado a la situación actual, para determinar en un segundo momento cuál es la conducta típica del delito de expolio. Para ello se tendrán en cuenta varias particularidades de los bienes encontrados en yacimientos arqueológicos: en primer lugar, su carácter demanial, que determina un tratamiento distinto del que se otorga a la cosa perdida y al tesoro oculto; en segundo lugar, el hecho de que en ellos concurre un valor puramente material, vinculado generalmente con la posibilidad de su apropiación y su valoración en dinero, y un valor inmaterial, derivado del contexto arqueológico en el que aparecen, que facilita una información sumamente valiosa a los estudiosos, información que se pierde cuando la pieza es separada de su entorno sin la previa aplicación de una metodología arqueológica, lo que afecta de manera decisiva a su función social ${ }^{5}$. A su vez, esa deslocalización daña al yacimiento en su conjunto, al perderse información a raíz del apoderamiento (por la desaparición de la pieza, pero también por la remoción de tierras), sin perjuicio de que pueda producir, a mayores, la destrucción o el menoscabo de los bienes muebles o inmuebles que lo integran. El objetivo último de este estudio es arrojar luz sobre una cuestión muy concreta que, pese a su im-

4 Así, RODRÍGUEZ MORO, L.: "Críticas, incongruencias y dudas en la regulación penal de los delitos sobre el patrimonio histórico español antes y después de la reforma del Código Penal operada por la LO 1/2015, de 30 de marzo", en AA.VV.: IV Encuentro Profesional sobre lucha contra el tráfico ilícito de bienes culturales. Regulación penal de la protección del patrimonio histórico español, Madrid, 2016, p. 98.

5 Vid. entre otros, ANTÓN Y ABAJO, A.: "El delito de expolio y su problemática concursal (Un caso paradigmático: la SAP Lleida, Sección 1a, de 20 de marzo de 2019)", en Diario La Ley núm. 9508, 29 de octubre de 2019; GARCÍA CALDERÓN, J. M.: La defensa penal del patrimonio arqueológico, Madrid, 2016, p. 52. 
portancia para conseguir una adecuada protección del patrimonio histórico de nuestro país, sigue siendo objeto de debate en la doctrina y la jurisprudencia: ¿cómo se debe castigar el apoderamiento de bienes encontrados en yacimientos arqueológicos por su descubridor? Conviene advertir, por tanto, que no se pretende realizar una exposición sobre el tratamiento de la apropiación de bienes culturales por cualquier persona, en general, sino exclusivamente sobre el apoderamiento de los bienes que se encuentran en yacimientos arqueológicos por parte de quien los descubre.

\section{Del hurto de hallazgo a la apropiación indebida de cosa perdida}

El apoderamiento de bienes encontrados en yacimientos arqueológicos se ha castigado a lo largo de la codificación española como un delito contra la propiedad o contra el patrimonio. Esta protección se ha articulado sin mencionar específicamente esa procedencia, sino refiriéndose con carácter general a cosas perdidas o, más específicamente, a tesoros ocultos, conceptos civiles en los cuales se ha buscado el encaje de los bienes que nos ocupan.

En el Código Penal de 1822 (en adelante, CP 1822), un delito de estas características se recogía entre los delitos de hurto, siendo conocido como "hurto de cosa perdida". En efecto, en este primer Código Penal español, el art. 752 CP 1822 castigaba a "cualquiera que retenga la cosa agena que se ha encontrado, sabiendo quién es su dueño, ó pasando cuarenta y ocho horas sin anunciar al público el hallazgo, ó dar cuenta de él á la autoridad local... sufrirá una multa igual al valor de la misma cosa, y de los perjuicios que su falta hubiere causado ó causare al dueño, poseedor ó tenedor, y se le impondrá ademas un arresto de diez días á dos meses". Aunque no se hacía referencia expresa al tesoro oculto ${ }^{6}$, se entendía que este cabía en el concepto de "cosa

6 De acuerdo con el art. 352 del Código Civil (en adelante, CC), "Se entiende por tesoro, para los efectos de la ley, el depósito oculto o ignorado de dinero, alhajas u otros objetos preciosos cuya legítima pertenencia no conste". 
ajena encontrada", por aplicación de las leyes civiles en vigor. Se castigaba tanto la apropiación de lo encontrado, si el autor conocía al dueño de lo hallado, como la omisión del deber civil de declarar el hallazgo, si tal conocimiento no existía. Esa declaración podía hacerse de dos formas: bien con anuncios al público, reteniendo la cosa, bien con entrega de la cosa a la autoridad local. En esta primera regulación codificada, la pena era menor que la prevista para la figura básica del hurto. Mientras que el límite superior de la pena era idéntico en los dos casos, el límite mínimo era de diez días de arresto y multa en el hurto de hallazgo, pero ascendía a un mes en el tipo básico de hurto. A ello se sumaba que no era posible aplicar al hurto de hallazgo las circunstancias agravantes del hurto, contenidas en los arts. 749 y 750 CP 1822, ya que el primero se remitía a "los casos de los dos artículos precedentes", y el segundo a "los hurtos de los artículos 745, 748 у 749".

El hurto de hallazgo desaparece en el Código Penal de 1848 , así como en el texto fruto de la reforma de 1850, lo que abría paso a dos posibles interpretaciones: o bien la conducta había devenido en atípica ${ }^{7}$, o bien se encuadraba en el tipo básico de hurto, entonces contenido en el art. 437 CP $1848^{8}$. La ausencia de condenas durante el período de vigencia de los Códigos de 1848 y 1850 abonaría la primera interpretación.

El Código Penal de 1870 reintroduce la figura de hurto de cosa perdida, regulándola en el mismo precepto que el hurto propio y castigándola ahora con la misma pena. El art. 530.2 CP 1870 sanciona a "los que encontrándose una cosa perdida,

7 En este sentido, entre otros, GROIZARD Y GÓMEZ DE LA SERNA, A.: El Código Penal de 1870 concordado y comentado. Tomo VI, Salamanca, 1896, p. 281, quien afirmaba que "la consecuencia práctica de este silencio fué que los tribunales no castigaran en caso alguno como delito aquel hecho".

8 Así lo entendía SALVÁ, F.: "Estudios sobre el Código Penal. Los hurtos", en Revista General de Legislación y Jurisprudencia, tomo XXXV, 1869, para quien podían ser objeto de hurto las cosas ajenas, y ajeno es lo que no es propio, incluyendo "las cosas encontradas, así como las recibidas por error del que las remite". 
y sabiendo quién es su dueño, se la apropiaren con intencion de lucro". En la doctrina se apunta ya que la conducta presenta más parecido con la apropiación indebida que con el hurto9. No se hace referencia expresa a la cosa de dueño desconocido, lo cual llevó a que algunos autores sostuvieran que había delito de hurto por tratarse de la apropiación de cosa ajena, aunque se ignorase quién era el dueño ${ }^{10}$, mientras que otros entendían que quien encuentra no toma propiamente el objeto ${ }^{11}$, siendo esta la posición la adoptada por la jurisprudencia, que pese a todo asimilaba al hurto el hallazgo y apropiación del tesoro ${ }^{12}$.

Por su parte, el Código Penal de 1928 mantiene el hurto de cosa perdida en el art. $703.4^{\circ}$, que castiga con la pena del hurto propio a quien encuentra una cosa perdida de dueño conocido y se la queda, pero se añade también el caso de que no sea conocido el dueño y, en vez de consignarla a los efectos del Código Civil, el descubridor se la apropie. Además, también se regula el caso quien encuentra un tesoro y se apropia "en todo o en parte de la cuota que las leyes civiles atribuyen al propietario con conocimiento de quién es éste" (art. 703.5 CP 1928). Por primera vez aparece una agravación del hurto aplicable si los objetos sustraídos fueran artísticos o históricos existentes en monumentos, museos o edificios públicos (art. $705.3^{\circ} \mathrm{CP} 1928$ ).

El Código Penal de 1932 castigaba con las mismas penas del hurto propio la apropiación con intención de lucro de un bien perdido como hurto de cosa perdida (art. 505.2 ${ }^{\circ} \mathrm{CP} 1932$ ), pero no hacía referencia ni al tesoro oculto ${ }^{13}$ ni al subtipo agravado

9 Cfr. GROIZARD Y GÓMEZ DE LA SERNA, A.: El Código Penal de 1870, VI, cit., p. 279.

10 En este sentido, VIADA Y VILASECA, S.: Código Penal reformado de 1870. Tomo II, $4^{\mathrm{a}}$ ed. Madrid, 1890, p. 415.

11 Según indica JARAMILlO GARCÍA, A.: Novísimo Código Penal comentado y cotejado con el de 1870. Volumen II. Libros II y III. Artículos 215 al 858 , Salamanca, 1929, p. 337.

12 Así, las SSTS de 5 de mayo de 1884, 13 de mayo de 1896 o 14 de abril de 1900 , entre otras.

13 Un sector de la doctrina, contra el criterio de GROIZARD, entendía que el tesoro oculto del que se apropia el descubridor sin dar cuenta al dueño 
por la cualidad del bien sustraído. La misma redacción se mantiene en la versión original del Código Penal de 1944 (art. 514.2 CP 1944). En 1963 se introduce una disposición agravatoria común para todos los delitos contra la propiedad y el patrimonio en el art. 563 bis a) CP $1944^{14}$, aplicable "siempre que las cosas objeto del delito perseguido fueren de relevante interés histórico, artístico o cultural". Se trató probablemente de un error del legislador, pues la base 15 del art. 1 de la Ley 79/1961, de 23 de diciembre, de bases para la revisión y reforma del Código Penal y otras leyes penales, se refería a elevar las penas del delito de daños, y no de todos los delitos contra la propiedad y el patrimonio. Su existencia provocó no poca perplejidad, al superponerse a las agravaciones ya existentes en algunas figuras delictivas, como el hurto y el robo ${ }^{15}$. Pese a esa previsión, la regulación penal era tachada de insuficiente para proteger el patrimonio histórico ${ }^{16}$. En la modificación operada por la LO 8/1983, de 25 de junio, de Reforma Urgente y Parcial del Código Penal, lo que hasta entonces se había venido considerando hurto pasa a ser una forma de apropiación indebida. En efecto, se castiga con la misma pena que a los autores del tipo básico de

del terreno era una cosa perdida. Cfr. FERRER SAMA, A.: El delito de apropiación indebida, Murcia, 1944, pp. 477-478; del mismo autor, "Apropiación indebida", en MASCAREÑAS, C. E. (Dir.): Nueva Enciclopedia Jurídica. Tomo II, Barcelona, 1983, p. 775.

14 Art. 563 bis a) CP 1944: "Los hechos punibles comprendidos en el presente título serán castigados con la pena respectivamente señalada a los mismos, impuesta en el grado máximo, o con la inmediatamente superior en grado, al arbitrio del Tribunal, según las circunstancias y gravedad del hecho, las condiciones del culpable y el propósito que éste llevare, siempre que las cosas objeto del delito perseguido fueren de relevante interés histórico, artístico o cultural".

15 Vid., por ejemplo, las numerosas dudas planteadas por OROZCO PARDO, G./ PÉREZ ALONSO, E. J.: La tutela civil y penal del Patrimonio histórico, cultural o artístico, Madrid, 1996, pp. 279 ss.; SORIANO SORIANO, J. R.: Las agravantes especificas comunes al robo y hurto, Valencia, 1993, pp. 186-193.

16 Cfr. FERNÁNDEZ ALBOR, A.: "El patrimonio artístico y su protección penal", en AA.VV.: Estudios penales. Libro Homenaje al Prof. J. Antón Oneca, Salamanca, 1982, pp. 701-716. 
apropiación indebida "a los que encontrándose un bien perdido se lo apropiaren con ánimo de lucro" (art. 535 CP 1944/73, en la redacción posterior a la reforma de 1983). El cambio de nomen iuris tiene que ver con las críticas de un destacado sector doctrinal ${ }^{17}$, que señalaba que en el llamado "hurto de hallazgo" faltaba, entre otros elementos, una característica fundamental del hurto, el apoderamiento: en el hallazgo el autor no traslada la cosa del ámbito de poder del sujeto pasivo al propio. También apuntaba que el descubridor no toma "cosa ajena", puesto que le corresponde parte de ella. Sin embargo, el cambio no fue recibido acríticamente, pues se señaló que la apropiación de un bien perdido tampoco cumplía todos los requisitos de la apropiación indebida, delito que se caracteriza por el hecho de que el autor recibe la cosa, lo que no ocurre cuando se apropia de un bien perdido ${ }^{18}$. La reforma de 1983, haciéndose eco del mandato expreso de criminalización de los ataques al patrimonio histórico contenido en el art. 46 de la Constitución española de 1978 (en adelante, $\mathrm{CE})^{19}$, y confiando en la pronta aprobación de un

17 Cfr. BELTRÁN BALLESTER, E.: El hurto de hallazgo (Protección penal de la propiedad perdida en la legislación española, histórica y actual), Valencia, 1979, pp. 105-113; FERRER SAMA, A.: "El delito de apropiación indebida", cit., pp. 468 ss.; MUÑOZ CONDE en QUINTERO OLIVARES, G./ MUÑOZ CONDE, F.: La reforma penal de 1983, Barcelona, 1983, p. 145; QUINTANO RIPOLLÉS, A.: Comentarios al Código Penal. Vol. II, Madrid, 1946, p. 414; del mismo autor: Tratado de la parte especial del Derecho penal. Tomo II, Madrid, 1977, p. 201; QUINTERO OLIVARES, G.: "El hurto", en COBO DEL ROSAL, M. (Dir.): Comentarios a la legislación penal. Tomo V. Vol. 2, Madrid, 1985, pp. 1128-1130; RODRÍGUEZ RAMOS, L.: “Apropiación de lo hallado", en COBO DEL ROSAL, M. (Dir.), Comentarios a la legislación penal. Tomo V. Vol. 2, Madrid, 1985, p. 1274; del mismo autor, "Apropiación de la totalidad del tesoro oculto", en Cuadernos de Política Criminal, núm. 3, 1977, p. 291.

18 Así, QUINTANO RIPOLLÉS, A.: Tratado, II, cit., p. 206.

19 Sobre este mandato expreso de criminalización, vid., entre otros, GUISASOLA LERMA, C.: Delitos contra el patrimonio cultural. Artículos 321 a 324 del Código Penal, Valencia, 2001, pp. 57-61 y pp. 243 ss.; OTERO GONZÁLEZ, P./ ÁLVAREZ GARCÍA, F. J.: "La protección penal del patrimonio cultural en la Constitución Española (presupuestos constitucionales de la protección penal del Patrimonio Histórico)”, en Revista de Derecho 
nuevo Código Penal que acabaría demorándose otros doce años, se limitó a parchear la regulación penal introduciendo sendos subtipos agravados de los delitos de robo con fuerza (art. 506.7 CP 1944/73) y hurto (art. 516.2 CP 1944/73) cuando la conducta recaía sobre "cosas de valor histórico, cultural o artístico". Nada se preveía al respecto en los delitos de estafa, apropiación indebida y receptación ${ }^{20}$. Hubo que esperar a la aprobación del Código Penal de 1995 para que se produjeran nuevos cambios en la tutela penal frente a la conducta que nos ocupa.

\section{Los subtipos agravados de los delitos contra el patrimonio y otros delitos en el Código Penal de 1995 y las leyes penales especiales}

El Código Penal de 1995 introduce por primera vez un capítulo (el II del Título XVI) dedicado en exclusiva a los delitos sobre el patrimonio histórico, como respuesta al mandato a los poderes públicos de garantizar la conservación y promover el enriquecimiento del patrimonio histórico, cultural y artístico de los pueblos de España y de los bienes que lo integran, y de sancionar mediante la ley penal los atentados contra ese patrimonio. La existencia de un capítulo dedicado a los delitos sobre el patrimonio histórico no significa que todos los preceptos en los que se tutela este patrimonio estén ahí concentrados. En otras ubicaciones del Código Penal se podían y se pueden encontrar numerosos preceptos que protegen expresamente el patrimonio histórico, tantos que se ha llegado a calificar la situación de

Penal, núm. 35, 2012, pp. 35-65; RENART GARCÍA, F.: El delito de daños al patrimonio cultural español. Análisis del art. 323 del Código Penal de 1995, Granada, 2002, pp. 111 ss.; SALINERO ALONSO, C.: La protección del patrimonio histórico en el Código penal de 1995, Barcelona, 1997, pp. 133 ss.

20 Críticamente, vid. en su día RUIZ VADILLO, E., "La punición de los delitos de robo con fuerza en las cosas, hurto y estafa en la reforma parcial de Código Penal de 1983”, en Estudios Penales y Criminológicos, Vol. VII, 1984, pp. 323 ss.; SORIANO SORIANO, J. R.: Las agravantes especificas, cit., p. 166. 
"fraude de etiquetas", al existir más preceptos relativos al patrimonio histórico fuera del capítulo destinado a su protección que en él ${ }^{21}$. En la actualidad, baste citar las agravaciones de los delitos de hurto (art. 235.1.1), robo con fuerza en las cosas (art. 241.4), estafa (art. 250.1.3), administración desleal (art. 252) ${ }^{22}$, apropiación indebida (art. 253) ${ }^{23}$, apropiación de cosa mueble ajena (art. 254.1, que aludía a cosa mueble perdida antes de la reforma operada por la LO 1/2015), receptación (art. 298.1 a), introducido en la reforma de $2015^{24}$ ), delitos sobre la ordenación del territorio y el urbanismo (art. 319.1) y contra las personas y

21 PÉREZ ALONSO, E. J.: "Los delitos contra el patrimonio histórico en el Código penal de 1995", en Actualidad Penal, 1998-2, marginal 617, en expresión que se ha hecho viral. También críticamente, vid. GARCÍA CALDERÓN, J.: La defensa penal, cit., pp. 221-225; GUISASOLA LERMA, C.: Delitos, cit., p. 418; de la misma autora, "Evolución de los delitos del patrimonio histórico español en nuestro Código Penal, ayer y hoy", en AA.VV.: IV Encuentro Profesional sobre lucha contra el tráfico ilicito de bienes culturales. Regulación penal de la protección del patrimonio histórico español, Madrid, 2016, p. 77; RUFINO RUS, J.: "La protección del patrimonio arqueológico en el Código Penal. Deficiencias y propuestas para una reforma de las leyes sustantivas y procesales", en PH: Boletín del Instituto Andaluz del Patrimonio Histórico, núm. 82, 2012, p. 61.

22 Con arreglo al tenor literal del art. $252 \mathrm{CP}$, que se remite en cuanto a la asignación de las penas al art. $250 \mathrm{CP}$, hay que entender que al delito de administración desleal le son de aplicación las agravaciones de la estafa, incluida la que se refiere a bienes que integren el patrimonio artístico, histórico, cultural o científico. En este sentido, entre otros, MARTÍNEZ-BUJÁN PÉREZ, C.: El delito de administración desleal de patrimonio ajeno, Valencia, 2016, pp. 111-112; también GALLEGO SOLER, J. I.: “Art. 252”, en CORCOY BIDASOLO, M./ MIR PUIG, S.: Comentarios al Código Penal. Reforma LO 1/2015 y LO 2/2015, Valencia, 2015, p. 886.

23 También aquí, con arreglo al tenor literal del art. 253.1 CP, que se remite en cuanto a la asignación de las penas al art. $250 \mathrm{CP}$, hay que entender que son de aplicación a la apropiación indebida las agravaciones de la estafa, incluida la que se refiere a bienes que integren el patrimonio artístico, histórico, cultural o científico. En este sentido, entre otros, GALLEGO SOLER, J. I.: “Art. 253”, en CORCOY BIDASOLO, M./ MIR PUIG, S.: Comentarios al Código Penal. Reforma LO 1/2015 y LO 2/2015, Valencia, 2015, p. 891.

24 Reclamaban un delito específico de receptación referido expresamente a los bienes culturales, entre otros, ALMELA VICH, C.: "Delitos sobre el patrimonio histórico", en Actualidad Penal, 2000-3, marginal 873; GARCÍA CALDERÓN, J. M.: "La relación”, cit., p. 83. 
bienes protegidos en caso de conflicto armado (art. 613.1). En el pasado, también cabía incluir en este listado la malversación agravada cuando las cosas malversadas hubieran sido declaradas de valor histórico o artístico (art. 432.2, derogado en 2015 25 ) y la falta de daños cuyo importe no excediere de 50.000 pesetas cuando los daños se causaran en bienes de valor histórico, artístico, cultural o monumental (art. 625.2 CP, según la redacción original de 1995, modificada por la LO 15/2003, de 25 de noviembre, para hacer referencia a daños causados "en los lugares o bienes a que se refiere el artículo 323 de este Código", texto finalmente derogado en 2015). A estos preceptos había que añadir, además, los delitos recogidos en leyes penales especiales: por un lado, los delitos contra el patrimonio histórico recogidos en el art. 77 de la LO 13/1985, de 9 de diciembre, por la que se aprueba el Código Penal Militar -hoy derogado, sin que el nuevo Código Penal Militar, aprobado por LO 14/2015, de 14 de octubre, contenga delito alguno relativo a la protección de bienes culturales-; y, por otro, el delito de contrabando de bienes pertenecientes al patrimonio histórico español, recogido en el art. 2.2 a) de la LO 12/1995, de 12 de diciembre, de represión del contrabando ${ }^{26}$, y antes en el art. 3.4 del Decreto 2166/1964,

25 Se ha dicho que la derogación de la malversación agravada no significa que el valor histórico, artístico, cultural o científico del bien malversado no tenga efectos agravatorios, debido a la remisión que hace el art. $432.2 \mathrm{CP}$ al art. $253 \mathrm{CP}$, que a su vez se remite a las penas de los arts. 249 y $250 \mathrm{CP}$, siendo así que este último recoge una agravación de la estafa por afectar a ese tipo de bienes. Cfr. ROMA VALDÉS, A.: "La estafa agravada por el valor cultural del objeto y la falsificación de obras de arte y antigüedades", en La Ley Penal, núm. 116, 2015. Le sigue OTERO GONZÁLEZ, P.: "Protección penal", cit., p. 360. Frente a esta opinión, hay que apuntar que la remisión del art. 432.2 CP al art. 253 CP es a los efectos de la descripción de la conducta típica, no de las penas.

26 Sobre esto, vid. FARALDO CABANA, P.: "El delito de contrabando de bienes integrantes del patrimonio histórico español. Comentario al art. 2.1 e) de la Ley Orgánica 12/1995, de 12 de diciembre, de represión del contrabando", en SERRANO-PIEDECASAS FERNÁNDEZ, J. R./ DEMETRIO CRESPO, E. (Dirs.): El derecho penal económico y empresarial ante los desafios de la sociedad mundial del riesgo, Madrid, 2010, pp. 223-258. 
de 16 de julio, por el que se adapta la Ley de Contrabando a la Ley General Tributaria.

En lo que se refiere al apoderamiento de bienes encontrados en yacimientos arqueológicos, antes de la introducción del delito de expolio se discutía si eran aplicables o no los subtipos agravados de los delitos contra el patrimonio, por las dudas relativas a la ajenidad de la cosa, y cuál era el objeto de protección, dada la disparidad de las referencias al patrimonio histórico. Además, se criticaba que esa tutela patrimonial se basara en un sistema de cuantías que no se entendía apropiado para los bienes procedentes de yacimientos arqueológicos, al no tener en cuenta el daño causado al yacimiento en su conjunto, por lo que para valorarlo adecuadamente se consideraba necesario aplicar un concurso con el delito de daños al patrimonio histórico español, concurso cuya naturaleza, como veremos en el siguiente apartado, era objeto de intenso debate en la doctrina y la jurisprudencia. Todos estos aspectos dificultaban la aplicación de los delitos de apoderamiento patrimonial en los casos que nos ocupan, como veremos a continuación.

\section{Obstáculos a la protección penal a través de los delitos de apoderamiento patrimonial}

\section{a. La consideración de los bienes encontrados en yaci- mientos arqueológicos como cosas perdidas o un tesoro ocul- to del que se apodera o se apropia el descubridor}

Bajo la vigencia de los códigos penales anteriores al actual, la inexistencia de un delito específico de apoderamiento de bienes de valor histórico, artístico, cultural o científico llevó a doctrina y jurisprudencia a aplicar a esa conducta los delitos contra la propiedad o el patrimonio. Para aplicar el hurto de

Vid. también RENART GARCÍA, F.: "Aspectos sustantivos del delito de contrabando de bienes culturales", en Revista de Derecho Penal y Criminología, núm. 10. 2002, pp. 143-198. 
hallazgo resultaba fundamentar entender que los bienes encontrados en yacimientos arqueológicos eran cosas perdidas de las que se apoderaba el descubridor. Esta fue la posición adoptada por la jurisprudencia ${ }^{27}$. Se entendía por cosa perdida la que queda desvinculada del ámbito de guarda y custodia de su poseedor involuntariamente. De acuerdo con el Código Civil, la cosa mueble perdida debe ser devuelta a su anterior poseedor, si es conocido, o consignada en poder del Alcalde del pueblo en conde se hubiera verificado el hallazgo, de no serlo (art. 615 CC). Ahora bien, además de la cosa perdida, la normativa civil regulaba específicamente el llamado tesoro oculto ${ }^{28}$. A diferencia de la cosa perdida, que tiene dueño que puede ser hallado, el tesoro oculto carece de dueño conocido sin posibilidad de hallarlo, pues no consta su legítima pertenencia, motivo por el cual el art. $351 \mathrm{CC}$ atribuye su propiedad al dueño del terreno en que se hallare, salvo que el descubrimiento fuera hecho en propiedad ajena, o del Estado, y por casualidad, en cuyo caso "la mitad se aplicará al descubridor". Por su parte, el art. 614 CC dispone que "el que por casualidad descubriere un tesoro oculto en propiedad ajena tendrá el derecho que le concede el artículo 351 de este Código" ${ }^{29}$. Como cabe observar, es necesario para

27 SSTS de 13 de mayo de 1896, 7 de febrero de 1899, 28 de noviembre de 1906, 22 de noviembre de 1930, 23 de enero de 1957, 24 de enero de 1977, 5 de mayo de 1984.

28 De acuerdo con el art. $352 \mathrm{CC}$, como hemos visto, "[s]e entiende por tesoro, para los efectos de la ley, el depósito oculto o ignorado de dinero, alhajas u otros objetos preciosos cuya legítima pertenencia no conste".

29 Sobre la regulación civil del tesoro oculto, en general, vid. MOREU BALLONGA, J. L.: "Artículo 351. Descubrimiento de tesoro oculto", en VALPUESTA FERNÁNDEZ, R., y otros (Dirs.): Código Civil comentado, Volumen 1, Cizur Menor, 2011, pp. 1422-1432, y comentarios a los preceptos concordantes. Sobre su aplicación por los tribunales, vid. RODRÍGUEZ ARROCHA, B.: "El tesoro en la jurisprudencia española", en Anales de la Facultad de Derecho, núm. 24, 2007, pp. 195-202. En relación con el patrimonio histórico, vid. LÓPEZ BELTRÁN DE HEREDIA, C.: "El régimen jurídico del tesoro oculto después de la Ley 16/1985, del Patrimonio Histórico Español", en BLASCO GASCÓ, F. de P., y otros (Coords.): Estudios jurídicos en homenaje a Vicente L. Montés Penadés. Tomo I, Valencia, 2011, pp. 1355-1379. 
aplicar la regulación del tesoro oculto que el descubrimiento se produzca por azar. Si el hallazgo se produce a consecuencia de una averiguación realizada con consentimiento del dueño del terreno, se considera que es este quien halla la cosa por medio de su descubridor ${ }^{30}$. Si el descubridor encuentra los bienes en el curso de una búsqueda que no realiza por cuenta del propietario, no tiene derecho a premio alguno ${ }^{31}$.

Esta regulación civil de la cosa perdida y el tesoro oculto planteaba dificultades respecto de la acción típica de los delitos de hurto y apropiación indebida ${ }^{32}$. Respecto del hurto, porque el dueño del terreno carece de la posesión material de la cosa ${ }^{33}$, además de que el descubridor es coproprietario y poseedor de ella, cuando el tipo penal exige que la cosa sea ajena y se encuentre en posesión de otra persona ${ }^{34}$. Desde otra perspectiva, se alegaba que los bienes encontrados en yacimientos no eran cosas ajenas, perdidas o de dueño desconocido, porque la titularidad pública establecida en el art. 44.1 LPHE solo comienza una vez producido el hallazgo, de forma que antes de ser descubierta la pieza no podía considerarse como un bien ajeno para el descubridor, pero tampoco como un bien que hubiera perdido la Administración, al no ser todavía su titular y desconocer su existencia. Y una vez encontrada la cosa no cabía hablar de una cosa de dueño

30 BAJO FERNÁNDEZ, M.: Manual de Derecho penal. Parte especial (Delitos patrimoniales y económicos), Madrid, 1987, p. 295.

31 En este sentido, entre otros, BARCELONA LLOP, J.: "El dominio público arqueológico", en Revista de Administración Pública, núm. 151, 2000, pp. 154-155.

32 Vid. una panorámica de los problemas en SALINERO ALONSO, C.: La protección, cit., pp. 215 ss.

33 Como ya apuntaba en su día BRAGADO CALVO, E.: El hallazgo. Doctrina, legislación y casos prácticos, Madrid, 1957, p. 99.

34 En este sentido, ROMA VALDÉS, A.: La aplicación de los delitos sobre el patrimonio cultural, Granada, 2008, pp. 69-72; del mismo autor: "La protección penal del patrimonio arqueológico", en AA.VV.: Estudios Jurídicos. Ministerio Fiscal. Vol. VIII, Madrid, 1998, pp. 3 ss.; del mismo autor: "Las excavaciones ilegales y la protección penal del patrimonio histórico", en Revista de Derecho Ambiental, núm. 17, 1996, pp. 59 ss. Vid. también OTERO GONZÁLEZ, P.: "El delito doloso”, cit., pp. 1195-1196. 
desconocido, porque pertenecía a la Administración ${ }^{35}$. Respecto de la apropiación indebida, porque de nuevo no estamos ante cosas perdidas o de dueño desconocido, sino que el descubridor es copropietario de la cosa, mientras que el delito requiere la ajenidad de la cosa de la que se apropia el sujeto activo ${ }^{36}$, a lo que se suma que el descubridor no se apropia de una cosa que recibe o le es confiada, sino que la encuentra. Estas dificultades llevaban a soluciones dispares, pues había quien optaba por el hurto ${ }^{37}$ y quien lo hacía por la apropiación indebida ${ }^{38}, \sin$ faltar quienes entendían que la conducta de apoderamiento de bienes encontrados en yacimientos no era subsumible en ningún precepto del Código Penal ${ }^{39}$.

35 Cfr. SALINERO ALONSO, C.: La protección, cit., p. 226. Ya hacía años que en la doctrina se decía que en el hurto la cosa había de ser indudablemente ajena, lo que no ocurre si la cosa estaba perdida o abandonada, y para el hurto de cosa perdida era necesario que la cosa no careciera de dueño. Cfr. LÓPEZ-REY Y ARROJO, M./ ÁLVAREZ VALDÉS, F.: El nuevo Código Penal, Madrid, 1933, pp. 482-483.

36 Según el art. $351 \mathrm{CC}$, como se ha visto, la mitad del tesoro oculto corresponde al descubridor no propietario del terreno.

37 Por ejemplo, SALINERO ALONSO, C.: La protección, cit., pp. 271-277, cuando el descubridor se apodera del objeto sin dar comunicación a la Administración. Vid. también MUÑOZ CONDE, F.: "El tráfico ilegal de obras de arte", en Estudios Penales y Criminológicos, Vol. XVI, 1993, p. 409.

38 Así, por ejemplo, FERRER SAMA, A.: "Apropiación indebida", cit., pp. 774 ss., quien distinguía según el tesoro fuera encontrado casualmente o en virtud de trabajos practicados al efecto, por encargo del dueño del terreno o por un tercero en virtud de propia iniciativa, y según el dueño conociera o no el hallazgo, para apreciar la apropiación indebida propia o la apropiación indebida de cosa perdida. Más recientemente, ALMELA VICH, C.: "Delitos", cit., marginales 888-889; PÉREZ ALONSO, E. J.: "Delitos", cit., marginales 624-625; ROMA VALDÉS, A.: La aplicación, cit., pp. 72-73.

39 Como sostuvo en su día RODRÍGUEZ RAMOS, L.: "Apropiación", cit., pp. 289 ss., y posteriormente SILVA CASTAÑO, M. L.: "Artículo 253", en COBO DEL ROSAL, M. (Dir.): Comentarios al Código penal. Volumen VIII. Delitos contra el patrimonio y contra el orden socioeconómico. Artículos 234 a 272, Madrid, 1999, pp. 471-472. Vid. también la SAP de Granada (Sección $1^{\text {a }}$ ) 650/2000, de 31 de octubre (JUR 2001\46032), que entiende que no cabe aplicar la apropiación de cosa perdida o de dueño desconocido porque no son cosas perdidas, pues no tienen dueño, ni son de dueño desconocido, pues la Administración no las hace suyas integrándolas en el 
Ahora bien, en realidad esta polémica no era trasladable en todos sus términos a todas las apropiaciones de bienes encontrados en yacimientos arqueológicos. La normativa administrativa estatal sobre patrimonio histórico señalaba, ya desde 1911, que "serán propiedad del Estado, á partir de la promulgación de esta ley, las antigüedades descubiertas casualmente en el subsuelo ó encontradas al demoler antiguos edificios" (art. 5, primer inciso, de la Ley de 7 de julio de 1911 sobre Excavaciones Arqueológicas, que también contemplaba una recompensa para el descubridor y para el dueño del terreno, pero sin atribuirles la propiedad del objeto ${ }^{40}$ ). Esta regulación relativa a la titularidad de los bienes arqueológicos encontrados casualmente se mantiene de manera muy similar en la Ley 16/1985, de 25 de junio, del Patrimonio Histórico Español, que deroga el texto de 1911

dominio público sino con el hallazgo; ni el hurto, ya que la Administración no goza de la posesión, "que es el bien jurídico protegido en las cosas muebles, al margen del derecho de propiedad sobre ellas; no pudiendo ampliarse el objeto de protección penal del hurto a aquella relación dominical que no llega a ser ni mediata, so pena de vulnerar el principio de legalidad", admitiendo la aplicación de esta figura delictiva en un solo supuesto: "únicamente cuando se trata de objetos sustraídos en excavaciones rechazadas por la administración o con su autorización cabría hablar de delito de hurto de bienes arqueológicos, pues en este caso se habría producido un acto de ocupación que permitiría afirmar la existencia de una posesión directa de la cosa aunque la efectiva extracción de los objetos del terreno no se haya llevado a cabo".

40 En el art. 5, segundo inciso, de la Ley de 7 de julio de 1911, se señalaba que "el descubridor recibirá, al hacer entrega de los efectos encontrados, en ambos casos, como indemnización, la mitad del importe de la tasación legal de dichos objetos, correspondiendo la otra mitad, en el segundo caso, al dueño del terreno". Sobre los motivos que impulsaron la aprobación de esta Ley, vid. RODRÍGUEZ TEMIÑO, I.: "Coleccionismo y expolio arqueológico: los comienzos de una relación problemática", en Cuadernos de prehistoria y arqueología de la Universidad de Granada, núm. 25, 2015, pp. 211-256. Su vigencia se mantuvo hasta la aprobación de la Ley 16/1985, de 25 de junio, de Patrimonio Histórico Español. Sobre su significado, vid. YÁÑEZ VEGA, A.: "Estudio sobre la Ley de Excavaciones y Antigüedades de 1911 y el Reglamento para su aplicación de 1912”, en MORA RODRÍGUEZ, G./ DÍAZ-ANDREU, M. (Eds.): La cristalización del pasado: génesis y desarrollo del marco institucional de la arqueología en España, Málaga, 1997, pp. 423-430. 
antes citado. Además, la Ley actual extiende esa regulación de los bienes descubiertos por azar a los encontrados en búsquedas dirigidas a dicho fin. El art. 44 de esta Ley dispone que "son bienes de dominio público todos los objetos y restos materiales que posean los valores que son propios del Patrimonio Histórico Español y sean descubiertos como consecuencia de excavaciones, remociones de tierra u obras de cualquier índole o por azar. El descubridor deberá comunicar a la Administración competente su descubrimiento en el plazo máximo de treinta días e inmediatamente cuando se trate de hallazgos casuales. En ningún caso será de aplicación a tales objetos lo dispuesto en el artículo 351 del Código Civil... El descubridor y el propietario del lugar en que hubiere sido encontrado el objeto tienen derecho, en concepto de premio en metálico, a la mitad del valor que en tasación legal se le atribuya, que se distribuirá entre ellos por partes iguales. Si fuesen dos o más los descubridores o los propietarios se mantendrá igual proporción"41.

Los bienes encontrados en yacimientos arqueológicos, por tanto, no son cosas perdidas ni pueden considerarse tesoros ocultos ${ }^{42}$. Son bienes cuya ajenidad es evidente, pues for-

41 Sobre la regulación del hallazgo en la amplia normativa autonómica sobre patrimonio histórico, vid. in extenso YÁÑEZ, A.: Patrimonio arqueológico $y$ derecho sancionador, Valencia, 2018, pp. 77 ss. Vid. también GALLEGO ANABITARTE, A.: “Arqueología y Derecho. Hallazgos, jurisprudencia, legislación, carta arqueológica y planeamiento", en Revista de Derecho Urbanístico y Medio Ambiente, núm. 200, 2003, pp. 92 ss.

42 Como apunta ALEGRE ÁVILA, J. M.: "El patrimonio arqueológico: aspectos de su régimen jurídico", en Patrimonio Cultural y Derecho, núm. 1, 1997, p. 126, "la declaración de demanialidad del dominio arqueológico arrumba definitivamente las construcciones de la doctrina civilista acerca de la adquisición del tesoro o hallazgo arqueológico". Incluso ha llegado a decirse que el art. 44 LPHE deroga implícitamente la regulación civil del tesoro oculto. En este sentido, por ejemplo, LÓPEZ BELTRÁN DE HEREDIA, C.: "El régimen jurídico", cit., pp. 1356-1357, sobre la base de que "prácticamente todos los objetos valiosos, cuya legítima pertenencia no conste, y han permanecido ocultos durante largo tiempo, serán portadores de valores culturales, valores considerados dignos de protección y, por tanto, del dominio público". Más comedido, PANTALEÓN PRIETO, F.: “Art. 351”, en PAZ-ARES RODRÍGUEZ, C., y otros: Comentario del Código Civil. Tomo I, 
man parte del dominio público ${ }^{43}$. La inclusión de los bienes en el dominio público tiene como consecuencia, entre otras, la atribución a la Administración titular de una serie de facultades y prerrogativas para su defensa y protección, entre las que destaca la potestad de recuperación posesoria en defensa del derecho de la Administración a poseer los bienes, derivado directamente de su naturaleza demanial, según se recoge en la Ley 33/2003, de 3 de noviembre, del Patrimonio de las Administraciones públicas, pero también la imposición de límites a las facultades de disposición, pues es necesaria la previa desafectación si la Administración quiere desprenderse de ellos. En cualquier caso, está claro que no son propiedad del dueño del terreno ni del descubridor, que no pueden adquirirlos por ocupación, ya que al declararse de dominio público quedan excluidos del tráfico jurídico privado, convirtiéndose en res extra commercium ${ }^{44}$.

Madrid, 1991, p. 985, entiende que solo ha quedado derogado el último párrafo del art. $351 \mathrm{CC}$, que dispone que "[s]i los efectos descubiertos fueren interesantes para las ciencias o las artes, podrá el Estado adquirirlos por su justo precio, que se distribuirá en conformidad a lo declarado".

43 Así se reconoce en la jurisprudencia. Vid. las SSAP de Islas Baleares (Sección 2a) 420/2010, de 23 de diciembre (ARP 2011\727), y de Toledo (Sección 2a) 84/2007, de 4 de diciembre (ARP 2008\167). Los bienes encontrados en yacimientos arqueológicos son, por tanto, propiedad de la Administración. Generalmente la autonómica, pues salvo ciertas excepciones la titularidad de los bienes arqueológicos corresponde a las comunidades autónomas. Vid. BARCELONA LLOP, J.: "El dominio público arqueológico", cit., pp. 141 ss.; del mismo autor: "Consideraciones sobre el régimen jurídico del patrimonio arqueológico", en FERNANDO PABLO, M. (Dir.): Patrimonio cultural y nuevas tecnologías: entorno jurídico, Salamanca, 2012, pp. 277 ss. Afirmaba la titularidad estatal ALEGRE ÁVILA, J. M.: Evolución y régimen jurídico del patrimonio histórico. Volumen II, Madrid, 1994, pp. 347 ss. En trabajos posteriores reconoce que la normativa de las comunidades autónomas suele atribuir el producto de lo descubierto a la propia comunidad autónoma. Cfr. ALEGRE ÁVILA, J. M.: "El patrimonio histórico español: régimen jurídico de la propiedad histórica", en Anuario de la Facultad de Derecho de la Universidad Autónoma de Madrid, núm. 19, 2015, p. 223.

44 Vid. en este sentido CORTÉS BECHIARELLI, E.: "Función social y tutela penal del patrimonio arqueológico", en Revista Penal, núm. 13, 2004, pp. 61-63, con cita de la STC 227/1988 de 29 de noviembre. Mantiene que la 
El descubridor se convierte en depositario legal de la cosa una vez comunicado el descubrimiento a la Administración, según dispone expresamente la Ley 16/1985 ${ }^{45}$. Antes de hacerlo, cabe entender que queda encargado de la custodia o cuidado de los bienes que descubre, respecto de los cuales tiene la disponibilidad fáctica -no jurídica-, con la obligación de comunicar su descubrimiento al titular, que es la Administración. Esa obligación es de cumplimiento inmediato cuando el descubrimiento es casual, y tiene un plazo de 30 días si responde a una búsqueda. Dado que el descubridor es un particular encargado de los bienes, y que los bienes arqueológicos son bienes públicos, antes de la introducción del delito de expolio no correspondía, en mi opinión, aplicar el delito de apropiación indebida en caso de que no comunicase su descubrimiento en tiempo y forma, como proponía un sector doctrinal ${ }^{46}$, ni la apropiación indebida de cosa perdida, como defendía otro ${ }^{47}$, pero tampoco los subtipos agravados de hurto ${ }^{48}$ o robo con fuerza, en su caso, como afir-

razón de ser del dominio público arqueológico es precisamente impedir que los particulares puedan ser propietarios de bienes de esta clase ALEGRE ÁVILA, J. M.: Evolución, II, cit., pp. 365 ss.

$45 \mathrm{El}$ art. 44.2 LPHE indica que "[u]na vez comunicado el descubrimiento, y hasta que los objetos sean entregados a la Administración competente, al descubridor le serán de aplicación las normas del depósito legal, salvo que los entregue a un museo público".

46 En este sentido, entre otros, GARCÍA CALDERÓN, J. M.: "La protección penal del patrimonio arqueológico", en Patrimonio Cultural y Derecho, núm. 7, 2003, p. 114; GARCÍA MAGNA, D.: "La protección penal frente al expolio del patrimonio cultural subacuático", en ÁLVAREZ GONZÁLEZ, E. M. (Dir.): Patrimonio arqueológico sumergido: una realidad desconoci$d a$, Málaga, 2009, p. 158. Esta opción contaba con apoyo jurisprudencial de cierta antigüedad. Vid. las SSTS de 5 de mayo de 1834, 5 de julio de 1901, 28 de noviembre de 1906, 1 de septiembre de 1939 (RJ 1939\117), 23 de enero de 1957 (RJ 1957\79), 24 de enero de 1977 (RJ 1977\72), entre otras.

47 Solo en caso de que el yacimiento no fuera conocido. En este sentido, CUESTA AGUADO, P. de la: "La reforma de los delitos contra el patrimonio histórico. El delito de expolio", en QUINTERO OLIVARES, G. (Dir.): Comentario a la reforma penal de 2015, Cizur Menor, 2015, p. 651.

48 Así, entre otros, PÉREZ MANZANO en BAJO FERNÁNDEZ, M. (Dir.): Compendio de Derecho Penal (Parte Especial), II, Madrid, 1998, p. 492; 
maba un tercer grupo de autores. Tampoco tenía mucho sentido la distinción que se hacía en ocasiones entre el descubrimiento realizado en yacimientos declarados como tales e inventariados, supuesto en el que el apoderamiento se castigaría como hurto agravado, y el realizado en lugares que no cuentan con esa declaración administrativa de tutela, que se castigaría como delito de daños sobre el patrimonio histórico, según algunos ${ }^{49}$, o de apropiación indebida, según otros ${ }^{50}$. En ambos casos estamos ante bienes integrantes del dominio público, por lo que, en mi opinión, el delito aplicable era la malversación de caudales públicos. Baste señalar al efecto que las disposiciones relativas a la malversación se extendían "[a] los que se hallen encargados por cualquier concepto de fondos, rentas o efectos de las Administraciones públicas" y "[a] los particulares legalmente designados como depositarios de caudales o efectos públicos" (art. 435.1 ${ }^{\circ}$

SALINERO ALONSO, C.: La protección, cit., p. 276, puntualizando que solo se aplicaría el hurto mientras no se hubiera comunicado el descubrimiento a las autoridades.

49 Cfr. ROMA VALDÉS, A.: "La protección penal", cit., pp. 15 ss.; del mismo autor: La aplicación, cit., pp. 68-72. En el mismo sentido, la Red de Fiscales Medioambientales de Andalucía, según se expone en la Memoria de la Fiscalía General del Estado de 2004. Esta tesis fue acogida en la SAP de Granada (Sección 1ª) 650/2000, de 31 de octubre (JUR 2001\46032). Por su parte, la SAP de Islas Baleares (Sección 2a) 420/2010, de 23 de diciembre (ARP 2011 727 ), aplica el delito de daños al patrimonio histórico en un caso de extracción de numerosas piezas de yacimientos arqueológicos subacuáticos cuya ubicación no llegó a ser identificada, pero en una comunidad autónoma, la de Islas Baleares, que había declarado monumentos históricoartísticos todos los monumentos megalíticos, cuevas prehistóricas y otros restos prehistóricos y protohistóricos de las islas de Mallorca y Menorca. La sentencia indica, en cualquier caso, que no haría falta para aplicar el delito de daños la previa catalogación del interés del yacimiento en cuestión.

50 Cfr. GARCÍA CALDERÓN, J. M.: "La protección penal”, cit., p. 114; del mismo autor: "La relación", cit., pp. 79-80; del mismo autor: La defensa penal, cit., pp. 238-240; GARCÍA MAGNA, D.: "La protección penal”, cit., p. 158; NÚÑEZ SÁNCHEZ, A.: "La nueva regulación penal”, cit., pp. 182183; OTERO GONZÁLEZ, P.: "El delito doloso", cit., p. 1196. Castiga por apropiación indebida en concurso ideal con daños en el patrimonio histórico por el apoderamiento de piezas procedentes de yacimientos no catalogados la SAP de Toledo (Sección 2a) 84/2007, de 4 de diciembre (ARP 2008\167). 
y $2^{\circ} \mathrm{CP}$ en la redacción de 1995), situaciones en las que cabe incluir al descubridor ${ }^{51}$; que se entendía pacíficamente por "efectos públicos" las "cosas muebles" 52 , "todos aquellos objetos o bienes (distintos del dinero)... susceptibles de valoración económica, con independencia de su inclusión o no entre los bienes inventariables de la Administración"53; y que la acción consistía, en su modalidad activa, en sustraer, esto es, en una apropiación, "es decir, separación definitiva de los caudales o efectos de la esfera de dominio público, privando a su propietario de los derechos inherentes a la misma" ${ }^{54}$. La malversación contemplaba, además, un subtipo agravado "si las cosas malversadas hubieran sido declaradas de valor histórico o artístico" (art. 432.2 CP en la redacción de 1995). Como veremos en el subapartado b), con esta redacción solo cabía aplicar el subtipo agravado a los bienes inventariados o declarados de interés cultural en los términos previstos en la Ley 16/1985, pero nada impedía aplicar el tipo básico a los bienes encontrados en yacimientos ${ }^{55}$. Surgía, eso sí, el problema de determinar la cuantía de lo sustraído, puesto que las penas dependían de que la sustracción no alcanzara la cantidad de quinientas mil pesetas, en cuyo caso de imponían penas de multa superior a dos y hasta cuatro meses, prisión de

51 Según un sector doctrinal, solo desde que se comunica el descubrimiento a la Administración, pues a partir de entonces el descubridor se convierte en depositario legal. En este sentido, por ejemplo, ROMA VALDÉS, A.: La aplicación, cit., pp. 68 ss., 72-73; SALINERO ALONSO, C.: La protección, cit., pp. 276-277.

52 ROCA AGAPITO, L.: El delito de malversación de caudales públicos, Barcelona, 1999, pp. 117 ss.; RODRÍGUEZ DEVESA, J. M./ SERRANO GÓMEZ, A.: Derecho Penal Español. Parte Especial, $18^{\mathrm{a}}$ ed. Madrid, 1995, p. 1182.

53 MORALES PRATS, F./ MORALES GARCÍA, O.: “Art. 432”, en QUINTERO OLIVARES, G. (Dir.): Comentarios a la Parte Especial del Derecho Penal, Cizur Menor, 1996, p. 1247.

54 MORALES PRATS, F./ MORALES GARCÍA, O.: “Art. 432”, cit., p. 1249.

55 Reconoce expresamente que se puede aplicar el tipo básico de malversación cuando las cosas malversadas no hubieran sido declaradas de valor histórico o artístico CASTRO MORENO, A.: La malversación de caudales públicos en el Código Penal de 1995, Valencia, 2001, p. 297, nota núm. 203. 
seis meses a tres años y suspensión de empleo o cargo público por tiempo de seis meses a un año, o sí lo hiciera, en cuyo caso la pena era de prisión de tres a seis años e inhabilitación absoluta por tiempo de seis a diez años (art. $432.3^{\circ} \mathrm{CP}$ en la redacción de 1995). A este problema de las cuantías, que también aparece en los delitos contra el patrimonio y en el contrabando, haremos referencia, a su vez, en el subapartado c).

\section{B. La determinación del objeto de protección}

A las dificultades de encaje en los tipos penales se añadía como obstáculo a la protección de los bienes procedentes de yacimientos que los delitos contra el patrimonio utilizaran -y sigan utilizando- expresiones para referirse a los bienes culturales que no solo no coinciden con las empleadas en la Constitución ${ }^{56}$ y en la variada normativa administrativa existente al respecto, tanto estatal como autonómica ${ }^{57}$, sino que tampoco lo hacen con las utilizadas en otros delitos íntimamente relacionados con ellos, como la receptación o el contrabando, lo que dificulta delimitar cuál es el objeto de protección de cada delito en concreto ${ }^{58}$. En efecto, se habla de "cosas de valor histórico, artístico, cultural o científico" (en los subtipos agravados del hurto, el robo con fuerza, la apropiación indebida de cosa mueble ajena y la recep-

56 El art. 46 CE menciona el "patrimonio histórico, artístico y cultural".

57 La Ley 16/1985 se refiere en su art. 1 al patrimonio histórico español, integrado por "los inmuebles y objetos muebles de interés artístico, histórico, paleontológico, arqueológico, etnográfico, científico o técnico". En la normativa autonómica se utiliza a veces la denominación de "patrimonio cultural" y en otras la de "patrimonio histórico", y las categorías empleadas para su protección pueden coincidir o no con las estatales. Vid. al respecto, ampliamente, LÓPEZ BRAVO, C.: "Interrelación de las categorías legales de protección del Patrimonio Cultural en España”, en PH: Boletín del Instituto Andaluz del Patrimonio Histórico, núm. 27, 1999 pp. 83-90; MARTÍNEZ DÍAZ, B./ QUEROL, M. A.: "La gestión del patrimonio arqueológico en las comunidades autónomas: balance y situación actual", en PH: Boletín del Instituto Andaluz del Patrimonio Histórico, núm. 48, 2004, pp. 101-109.

$58 \mathrm{Al}$ respecto, entre otros, FERNÁNDEZ APARICIO, J. M.: La protección penal del Patrimonio Histórico, Sevilla, 2004, p. 23; RUFINO RUS, J.: "La protección", cit., p. 59. 
tación, en estos dos últimos cambiando el orden de los adjetivos), de "bienes que integren el patrimonio artístico, histórico, cultural o científico" (en la estafa y, por remisión a su régimen penológico, en la administración desleal y la apropiación indebida) y de "bienes que integren el Patrimonio Histórico Español" (en el contrabando). También se habló en su día de cosas declaradas de valor histórico o artístico (en la malversación, en redacción ahora derogada).

La referencia a cosas de valor artístico, histórico, cultural o científico no puede reconducirse en exclusiva a los bienes incluidos en el inventario general del Patrimonio Histórico español o declarados de interés cultural ${ }^{59}$. En efecto, de acuerdo con la

59 Es doctrina mayoritaria. Así, entre otros, cfr. CORTÉS BECHIARELLI, E.: "Función social", cit., p. 65; GARCÍA ARÁN, M.: El delito de hurto, Valencia, 1998, pp. 154-155; GARCÍA CALDERÓN, J. M.: La defensa penal, cit., p. 237; GONZÁLEZ RUS, J. J.: "Delitos contra el patrimonio y contra el orden socioeconómico (II)", en COBO DEL ROSAL, M. (Dir.): Derecho penal español. Parte especial, $2^{\mathrm{a}}$ ed. Madrid, 2005, p. 463; GOYENA HUERTA, J.: "Hurto", en MUÑOZ CUESTA, J. (Coord.): El hurto, el robo y el hurto y robo de uso de vehículos, Pamplona, 1998, pp. 70-71; PÉREZ ALONSO, E. J.: "Delitos", cit., marginal 621; QUINTERO OLIVARES, G.: “Art. 235”, en QUINTERO OLIVARES, G. (Dir.): Comentarios a la Parte Especial del Derecho Penal, Cizur Menor, 1996, pp. 450-451; RENART GARCÍA, F., El delito, cit., pp. 254-264, 401-404; RUFINO RUS, J.: "La tutela del patrimonio arqueológico en el Código penal", en YÁÑEZ VEGA, A./ RODRÍGUEZ TEMIÑO, I./ ALMANSA SÁNCHEZ, J. (Dirs.): El expoliar se va a acabar. Uso de detectores de metales y arqueología: sanciones administrativas y penales, Valencia, 2018, pp. 482-483; del mismo autor: "La protección", cit., p. 59; SORIANO SORIANO, J. R.: Las agravantes especificas, cit., pp. 180-183; SOUTO GARCÍA, E. M.: Los delitos de hurto y robo, Valencia, 2017, pp. 91-92; TASENDE CALVO, J. J.: "Los hurtos cualificados", en TASENDE CALVO, J. J. (Dir.): Delitos contra el patrimonio. Delitos de apoderamiento, Madrid, 2004, pp. 21-23; VIVES ANTÓN, T. S./ GONZÁLEZ CUSSAC, J. L.: "Delitos contra el patrimonio y el orden socioeconómico (III)", en VIVES ANTÓN, T. S., y otros: Derecho Penal. Parte Especial, $3^{\mathrm{a}}$ ed. Valencia, 2010, p. 385; YÁÑEZ VEGA, A.: "Actividades ilícitas contra el patrimonio arqueológico. Sistemas punitivos penal y administrativo", en Cuadernos de prehistoria y arqueología de la Universidad de Granada, núm. 25, 2015, p. 27. En la jurisprudencia son clásicas las SSTS de 12 de julio de 1988 (RJ 1988\6558), 12 de noviembre de 1991 (RJ 1991\8049) y 14 de septiembre de 1992 (RJ 1992\7138). 
normativa extrapenal, "integran el Patrimonio Histórico Español los inmuebles y objetos muebles de interés artístico, histórico, paleontológico, arqueológico, etnográfico, científico o técnico. También forman parte del mismo el patrimonio documental y bibliográfico, los yacimientos y zonas arqueológicas, así como los sitios naturales, jardines y parques, que tengan valor artístico, histórico o antropológico... Los bienes más relevantes del Patrimonio Histórico Español deberán ser inventariados o declarados de interés cultural en los términos previstos en esta Ley" (art. 1.2 y 3 LPHE) ${ }^{60}$. Por lo tanto, basta que un bien tenga valor artístico, histórico, paleontológico, arqueológico, etnográfico, científico, técnico o antropológico para que pase a formar parte del patrimonio histórico español, sin necesidad de previa declaración administrativa al respecto, sin perjuicio de que los más importantes deben ser inventariados o declarados de interés cultural. Esto significa que estamos ante un elemento

En contra, al entender que "por cosa de valor histórico, cultural o artístico han de entenderse los bienes inventariados o declarados de interés cultural, en los términos previstos por la Ley", BAJO FERNÁNDEZ, M.: "Artículo 250", en COBO DEL ROSAL, M. (Dir.): Comentarios al Código penal. Tomo VIII. Delitos contra el patrimonio y contra el orden socioeconómico (Artículos 234 a 272), Madrid, 1999, p. 347 (cursivas en el original); BOIX REIG, J./ JUANATEY DORADO, C.: “Art. 321”, en VIVES ANTÓN, T. S. (Dir.): Comentarios al Código Penal de 1995. Volumen II, Valencia, 1996, pp. 1586 y 1588; MILANS DEL BOSCH Y JORDÁN DE URRÍES en DOMÍNGUEZ LUÍS, J. A., y otros: Delitos relativos a la ordenación del territorio y protección del patrimonio histórico, medio ambiente y contra la seguridad colectiva, Barcelona, 1999, p. 268; PÉREZ MANZANO en BAJO FERNÁNDEZ, M. (Dir.): Compendio de Derecho Penal (Parte Especial), II, Madrid, 1998, p. 467. Más recientemente, sobre la base de que no es posible una fórmula coherente de protección sin que exista una previa declaración formal que catalogue los bienes integrantes del patrimonio histórico, por razones de seguridad jurídica, vid. CÁCERES RUIZ, L.: Delitos contra el Patrimonio Histórico. Sustracción de cosa propia a su utilidad cultural, Madrid, 2008, pp. 68-70.

60 A mayores cabe señalar que el art. 2.1 e) del Real Decreto 1649/1998, de 24 de julio, por el que se desarrolla el Título II de la Ley Orgánica 12/1995, de 12 de diciembre, de represión del contrabando, relativo a las infracciones administrativas de contrabando, afirma que "son bienes que integran el Patrimonio Histórico Español los así definidos en su normativa específica”. 
normativo pendiente de valoración, que deberá concretar en cada caso el juez o tribunal en atención a las condiciones de la cosa y a la normativa extrapenal. Y es que no se puede afirmar que una cosa tiene valor artístico, histórico, cultural o científico a efectos penales si de acuerdo con la Ley 16/1985 no lo tiene, por lo que el prudente arbitrio del juez o tribunal se ve limitado, o mejor dicho, orientado por lo dispuesto en la legislación extrapenal ${ }^{61}$. Por su parte, la expresión "bienes que integren el patrimonio artístico, histórico, cultural o científico", utilizada en la estafa, debe entenderse en este mismo sentido que "cosas de valor artístico, histórico, cultural o científico", pues la diferencia con la anterior es puramente terminológica y carece de contenido propio ${ }^{62}$.

Cuando la expresión utilizada es "bienes que integren el Patrimonio Histórico Español", como en el contrabando, la discusión se centra en determinar si el objeto material debe limitarse a los bienes previamente inventariados o catalogados por la Administración, y a los declarados inexplotables como medida cautelar, o bien puede abarcar todos los bienes integrantes del Patrimonio Histórico Español, concepto que se configuraría así como un elemento normativo pendiente de valoración. La primera opción favorece la seguridad jurídica, pues solo podría integrar el objeto material del delito un bien previamente inventariado o catalogado por la Administración, o declarado inexplotable como medida cautelar ${ }^{63}$. La segunda opción, mayoritaria

61 En contra, afirmando que el juez no se encuentra vinculado a la especial regulación jurídico-administrativa VALLE MUÑIZ, J. M./ QUINTERO OLIVARES, G.: "De las defraudaciones", en QUINTERO OLIVARES, G. (Dir.): Comentarios al Código Penal. Tomo II. Parte Especial (Artículos 138 a 318), $5^{\text {a }}$ ed. Cizur Menor, 2008, p. 741, si bien admiten que pueda acudir a ella en su labor exegético-integradora.

62 Así, entre otros, CHOCLÁN MONTALVO, J. A.: El delito de estafa, $2^{\mathrm{a}}$ ed. Barcelona, 2009, pp. 243-249. Vid. también CONDE-PUMPIDO FERREIRO, C.: Estafas, Valencia, 1997, pp. 164-166; GARCÍA CALDERÓN, J. M.: La defensa penal, cit., pp. 235-236.

63 BAJO FERnÁndeZ, M./ BACIGALUPO, S.: Derecho Penal Económico, Madrid, 2001, p. 344; OROZCO PARDO, G./ PÉREZ ALONSO, E. J.: La 
en la doctrina ${ }^{64}$, permite extender la protección a bienes que, sin haber sido todavía inventariados o catalogados, merecen la misma protección que los que sí lo están por su valor histórico, artístico, cultural o científico. El juez o tribunal debe en este caso atender a las circunstancias del caso concreto y al momento social imperante para decidir si los bienes se integran en el patrimonio histórico español. Esta segunda posición es más coherente con la regulación administrativa del patrimonio histórico, de acuerdo con la cual, como se ha podido comprobar, "solo" "los bienes más relevantes del Patrimonio Histórico Español deberán ser inventariados o declarados de interés cultural en los términos previstos en esta Ley" (art. 1.3 LPHE).

Por el contrario, la mención que hacía el delito de malversación a las cosas declaradas de valor histórico o artístico, en la redacción hoy derogada, obligaba a entender que se trataba de bienes inventariados o declarados de interés cultural en los términos previstos en la Ley 16/1985 ${ }^{65}$. Esta exigencia de-

tutela civil y penal, cit., pp. 304-305; PÉREZ ALONSO, E. J.: "El delito de contrabando de bienes culturales", en La Ley Penal, núm. 52, año V, septiembre 2008, pp. 55-56; RODRÍGUEZ MOURULLO, G.: "El objeto de protección en los delitos contra el patrimonio histórico", en CARBONELL MATEU, J. C., y otros (Coords.): Estudios penales en homenaje al Profesor Cobo del Rosal, Madrid, 2005, pp. 782-784; ROMERO ESCABIAS DE CARBAJAL, J. A.: "Problemática jurídico-penal de la Ley de Contrabando de 1995", en SORIANO SORIANO, J. R. (Dir.): Delitos contra la salud pública y contrabando, Madrid, 2000, p. 314; VÁZQUEZ IRUZUBIETA, C.: Leyes complementarias del Código Penal. Doctrina y jurisprudencia, Madrid, 2011, p. 1108.

64 GÓMEZ DE LIAÑO POLO, G.: Delitos contra el patrimonio cultural, especial estudio de contrabando de patrimonio histórico artístico, Doc. Núm. 12/06, Madrid, 2001, pp. 14-15; LORENZO SALGADO, J. M.: "Contrabando", en BOIX REIG, J. (Dir.): Diccionario de Derecho penal económico, Madrid, 2008, pp. 259-260; MUÑOZ CONDE, F.: "El tráfico ilegal", cit., pp. 404-405; PÉREZ ALONSO, E. J.: "Delitos", cit., marginal 641.

65 Así, entre otros, CASTRO MORENO, A.: La malversación, cit., pp. 296297; ENTRENA FABRÉ, R.: El delito de malversación, Valencia, 1999, p. 73; GIMENO LAHOZ, R./ CORBELLA HERREROS, T.: "Delitos contra la Administración Pública. Título XIX”, en GANZENMÜLLER, C./ ESCUDERO, J. F./ FRIGOLA, J. (Coords.): Delitos contra la Administración 
bía entenderse en el sentido de que el bien hubiera sido objeto de inclusión previa en el Registro General de Bienes de Interés Cultural, adscrito a la Dirección General de Bellas Artes y Archivos del Ministerio de Cultura (arts. 21 a 23 del Reglamento, aprobado por Real Decreto 111/1986, de 10 de enero), o en el Inventario General de Bienes Muebles ${ }^{66}$ del Patrimonio Histórico Español, no declarados de interés cultural pero considerados de singular relevancia (arts. 26 a 34 LPHE y 24 a 32 RPHE). La necesidad de que el bien estuviera inventariado o hubiera sido declarado de interés cultural suponía una fuerte limitación de las posibilidades de aplicación del precepto, que según la doctrina se contradecía con el mandato constitucional de sanción penal a los atentados contra el patrimonio histórico, ya que el art. 46 $\mathrm{CE}$ alude a los bienes que integran dicho patrimonio "cualquiera que sea su régimen jurídico y su titularidad"67. Cabe destacar, no obstante, que en la jurisprudencia se había apreciado el valor histórico o artístico de los bienes malversados atendiendo no a su registro o inventario, sino a su integración en el patrimonio histórico español, con carácter general ${ }^{68}$. A mayores, no se en-

pública; contra la Administración de justicia, y contra la Constitución, Barcelona, 1998, p. 112; MORALES PRATS, F./ MORALES GARCÍA, O.: “Art. 432", cit., p. 1251; MUÑOZ CUESTA, J.: "El delito de malversación", en La Ley, 1996-5, p. 1572; ORTS BERENGUER, E.: "De la malversación", en VIVES ANTÓN, T. S. (Coord.): Comentarios al Código Penal de 1995. Volumen II (Arts. 234 a Disposiciones Finales), Valencia, 1996, p. 1856; PÉREZ ALONSO, E. J.: "Delitos", cit., marginal 626; ROCAAGAPITO, L.: El delito de malversación, cit., p. 217; ROLDÁN BARBERO, H.: El delito de malversación, Sevilla, 1996, p. 23; RUFINO RUS, J.: "La protección", cit., p. 59; SALINERO ALONSO, C.: La protección, cit., pp. 286-287.

66 Los bienes inmuebles integrados en el Patrimonio Histórico Español siempre tienen la categoría de bienes de interés cultural. Se trata de monumentos, jardines, conjuntos y sitios históricos, así como de las zonas arqueológicas.

67 En este sentido, cfr. MUÑOZ CONDE, F.: "El tráfico ilegal", cit., p. 405; ORTS BERENGUER, E.: "De la malversación", cit., p. 1856; ROCAAGAPITO, L.: El delito de malversación, cit., pp. 219-222.

68 Así, entre otras, las SSTS de 8 de abril de 1986 (RJ 1986\1945), 12 de julio de 1988 (RJ 1988\6558), 12 de noviembre de 1991 (RJ 1991\8049), 14 de abril de 1992 (RJ 1992\3053), 1849/1992 de 14 de septiembre (RJ 1992\7138). 
tendía que se hiciera mención expresa únicamente al valor histórico o artístico, olvidando el valor cultural o científico, al que también se alude en otros preceptos del Código Penal y en la normativa extrapenal ${ }^{69}$.

Dicho esto, queda por delimitar de qué "cosas" o "bienes" se trata. Al respecto, hay que tener en cuenta que el art. 44.1 LPHE dispone que "son bienes de dominio público todos los objetos y restos materiales que posean los valores que son propios del Patrimonio Histórico Español y sean descubiertos como consecuencia de excavaciones, remociones de tierra u obras de cualquier índole o por azar". Por su parte, el art. 40.1 LPHE señala que "forman parte del Patrimonio Histórico Español los bienes muebles o inmuebles de carácter histórico, susceptibles de ser estudiados con metodología arqueológica, hayan sido o no extraídos y tanto si se encuentran en la superficie o en el subsuelo, en el mar territorial o en la plataforma continental. Forman parte, asimismo, de este Patrimonio los elementos geológicos y paleontológicos relacionados con la historia del hombre y sus antecedentes". El aspecto definitorio de los bienes arqueológicos es, pues, que sean susceptibles de ser estudiados con metodología arqueológica ${ }^{70}$. Habrá de ser un/a arqueólogo/a quien se pronuncie al respecto en caso de duda.

\section{El uso de la cuantía para determinar la pena del apoderamiento de bienes procedentes de yacimientos ar- queológicos}

Tradicionalmente se ha señalado que la protección del patrimonio histórico a través de los delitos contra el patrimonio o de la malversación también se enfrenta al obstáculo de que la pena de estos delitos depende del valor de la cosa, siendo la utilización de este criterio muy criticada cuando se trata de bienes culturales, en general, y procedentes de yacimientos arqueológi-

69 Críticamente, SALINERO ALONSO, C.: La protección, cit., pp. 286-287.

70 Así, BARCELONA LLOP, J.: "El dominio público arqueológico", cit., pp. 151-152. 
cos, en particular. En efecto, se entiende mayoritariamente que se debe tener en cuenta no solo el valor de la pieza concreta, a veces muy difícil de concretar, muy reducido o, al contrario, incalculable o irreparable en la práctica, sino también el contexto arqueológico alterado en el curso de su obtención ${ }^{71}$. Ahora bien, lo cierto es que cuando la acción delictiva recae sobre bienes de valor artístico, histórico, cultural o científico, da igual que el valor de la cosa supere o no el límite 400 euros establecido en el hurto y la estafa para distinguir entre el delito leve y el menos grave: se aplica siempre el subtipo agravado correspondiente ${ }^{72}$.

71 Como proponían, entre otros, GARCÍA CALDERÓN, J. M.: "Los delitos sobre el Patrimonio Histórico Español. Los daños dolosos a los bienes culturales (artículo 323 del Código Penal)", en MORILLAS CUEVA, L. (Dir.): Estudios sobre el Código Penal reformado (Leyes Orgánicas 1/2015 y 2/2015), Madrid, 2015, pp. 749-750; del mismo autor: "La relación", cit., p. 82; del mismo autor: La defensa penal, cit., pp. 214 ss.; GUISASOLA LERMA, C.: "Delitos contra bienes culturales: una aproximación al concepto de expolio en Derecho penal”, en Revista General de Derecho Penal, núm. 27, 2017, pp. 3-4; de la misma autora: "Delitos sobre el patrimonio histórico: artículo 323 del CP”, en GONZÁLEZ CUSSAC, J. L. (Dir.): Comentarios al Código Penal de 2015, 2a ed. Valencia, 2015, pp. 1004-1005; MARTÍNEZ DÍAZ, B.: "Análisis y propuestas sobre el expolio del Patrimonio Arqueológico", en Boletín del Museo Arqueológico Nacional, tomo XIV, núms. 1-2, 1996, pp. 192-193; NÚÑEZ SÁNCHEZ, A.: "La nueva regulación penal", cit., pp. 178-179; OTERO GONZÁLEZ, P.: "El delito doloso", cit., pp. 1189-1190; RODRÍGUEZ TEMIÑO, I.: "Ciencia arqueológica, patrimonio arqueológico y expolio", en AA.VV.: La protección del patrimonio arqueológico contra el expolio, Sevilla, 2002, p. 27; RUFINO RUS, J.: "La tutela", cit., pp. 487, 493-495; del mismo autor: "La protección", cit., pp. 61-62. ROMA VALDÉS, A.: "La valoración de los daños arqueológicos y la justicia cautelar en el proceso penal”, en PH: Boletín del Instituto Andaluz del Patrimonio Histórico, núm. 82, 2012, pp. 72-73, incluye en el importe de los desperfectos los gastos relacionados con la intervención arqueológica que resulte necesaria para averiguar la información perdida: los gastos personales y materiales que implica la remoción de tierras, a los que suman los derivados del traslado de al menos una parte de la tierra a un vertedero autorizado; los gastos derivados del levantamiento topográfico; y los gastos del personal técnico encargado de la actividad arqueológica a realizar no solo en la excavación, sino también en la conservación del material o en la elaboración de la memoria.

72 En la jurisprudencia se entiende que la modalidad agravada de hurto que nos ocupa constituye un tipo autónomo al que no cabe extender la exigencia de 
En el robo con fuerza y la receptación no existe ese límite, pero en cualquier caso se aplica un subtipo agravado cuando se trate de cosas de valor artístico, histórico, cultural o científico. En la malversación se atiende al valor del perjuicio causado o de los bienes o efectos apropiados para fijar la pena aplicable. El problema de la cuantía también es de gran relevancia en la apropiación indebida y en la apropiación de cosa mueble ajena, pues en tales casos la pena prevista cuando se trate de cosas de valor artístico, histórico, cultural o científico se degrada a multa "si la cuantía de lo apropiado no excediere de 400 euros" (arts. 253.2 y $254.2 \mathrm{CP}$ ); y en el delito de contrabando, que se aplica "siempre que el valor de los bienes, mercancías, géneros o efectos sea igual o superior a 50.000 euros" (art. 2.2 a) LORC), convirtiéndose en infracción administrativa si no se alcanza ese valor. Pero la ubicación entre los delitos contra el patrimonio histórico no es óbice para la utilización de cuantías. También se usan en los delitos de daños sobre el patrimonio histórico. Los daños causados por imprudencia grave en bienes de valor artístico, histórico, cultural, científico o monumental, así como en yacimientos arqueológicos, solo son penalmente típicos si superan la cuantía de 400 euros (art. 324 CP). Esta previsión reintroduce el problema de la determinación de la cuantía en el análisis de los delitos dolosos de daños, puesto que las defensas pedirán habitualmente la absolución y, subsidiariamente, la aplicación de la modalidad imprudente, lo que obligará a determinar la cuantía del perjuicio causado.

una cuantía superior a 400 euros propia del tipo básico. En este sentido, por ejemplo, las SSTS de 12 de julio de 1988 (RJ 1988\6558), 12 de noviembre de 1991 (RJ 1991\8049), 14 de septiembre de 1992 (RJ 1992\7138), y la SAP de Alicante (Sección 2a) 354/2002, de 14 de octubre (JUR 2002\286521). Sin embargo, la SAP de Soria (Sección $1^{\text {a }}$ ) 60/2003, de 22 de octubre (JUR 2004\42085), da a entender que sí es necesario que la cuantía supere los 400 euros para aplicar el subtipo agravado. En la doctrina la cuestión es polémica. A favor de que se prescinde de la cuantía, vid. NÚÑ̃Z SÁNCHEZ, A.: "La nueva regulación penal", cit., p. 195. En contra, sobre la base de que los daños por cuantía inferior a 400 euros han quedado despenalizados, vid. GARCÍA CALDERÓN, J. M.: "Los delitos”, cit., pp. 760-763. 
La reforma de 2015 incluye un segundo párrafo en el art. $323 \mathrm{CP}$, de acuerdo con el cual "[s]i se hubieran causado daños de especial gravedad o que hubieran afectado a bienes cuyo valor histórico, artístico, científico, cultural o monumental fuera especialmente relevante, podrá imponerse la pena superior en grado a la señalada en el apartado anterior". Con esta previsión es posible sostener una interpretación que no se limite a tener en cuenta la cuantía económica del perjuicio causado, sino que abarque tanto la pérdida de la función social del bien expoliado, derivada de su deslocalización y consiguiente desaparición del contexto arqueológico, como la afectación o el menoscabo de la función social del yacimiento del que ha sido extraído y de su propia integridad física ${ }^{73}$.

Dicho esto, en mi opinión, los gastos de restauración y los estudios previos a la intervención en los bienes expoliados deben tenerse en cuenta para el cálculo de la responsabilidad civil, pero no para la aplicación del subtipo agravado.

\section{Los problemas concursales}

Antes de la reforma de 2015, la doctrina vacilaba respecto de la calificación jurídico-penal del apoderamiento de bienes procedentes de yacimientos arqueológicos. Algunos autores entendían que si la sustracción "dañaba" o "depreciaba" de alguna forma el yacimiento, es decir, al conjunto, al privarle de uno de sus elementos que pudiera ser necesario para determinarlo correctamente, por ejemplo, en un contexto histórico y espacial determinado, podía castigarse por el art. $323 \mathrm{CP}$, que recogía el delito de daños al patrimonio histórico. De no ser así, se proponía aplicar únicamente el correspondiente subtipo agravado de los delitos contra el patrimonio, fuera hurto o apropiación indebida $^{74}$. También se acudía al concurso de delitos ${ }^{75}$, que

73 En la línea apuntada por OTERO GONZÁLEZ, P.: "Protección penal”, cit., p. 352; de la misma autora: "El delito doloso", cit., pp. 1200-1201.

74 Un sector doctrinal consideraba que el apoderamiento de piezas arqueológicas podía ser calificado de hurto agravado, conforme al art. 235.1.1 $1^{\circ} \mathrm{CP}$, cuando el yacimiento del que son extraídas las piezas ha sido objeto de 
podía ser ideal, medial o real. Se proponía el concurso ideal ${ }^{76}$ o medial cuando se causaban daños en el bien para conseguir apoderarse de él ${ }^{77}$, y el concurso real en otro caso ${ }^{78}$. Ahora bien,

declaración administrativa. De no ser así, proponía la aplicación del delito de apropiación indebida del art. 254 CP. Cfr. ANTÓN Y ABAJO, A.: "El delito de expolio", cit.; OTERO GONZÁLEZ, P., "Protección penal", cit., p. 348; ROMA VALDÉS, A., "La protección penal", cit., pp. 15 ss. Otros autores, como SALINERO ALONSO, C., La protección, cit., pp. 276-277, entendían que se aplicaba la apropiación indebida antes de comunicar el hallazgo a la Administración, y el hurto o el robo después de haberlo hecho, lo cual resulta, como poco, sorprendente, ya que es precisamente después de haber comunicado el hallazgo cuando el descubridor tiene la cosa en depósito legal, título que justificaría acudir a la apropiación indebida o a la malversación.

75 Así, ARIAS EIBE, M. J.: El patrimonio cultural. La nueva protección en los arts. 321 a 324 del Código penal de 1995, Granada, 2001, p. 209; GUISASOLA LERMA, C.: Delitos, cit., pp. 677-679; MARTÍNEZ-BUJÁN PÉREZ, C.: Derecho penal económico y de la empresa. Parte especial, $4^{\mathrm{a}}$ ed. Valencia, 2013, p. 993; RENART GARCÍA, F.: El delito, cit., p. 466 y 468; SALINERO ALONSO, C.: La protección, cit., p. 316; TASENDE CALVO, J. J.: "Los hurtos cualificados", cit., p. 26. Defendía el concurso aparente de leyes penales, a resolver por consunción a favor del robo con fuerza agravado por el valor histórico, cultural, etc. del bien, cuando el menoscabo ocasionado era consecuencia de la fuerza implícita en el robo, OTERO GONZÁLEZ, P.: "Protección penal”, cit., p. 358. Si los desperfectos excedían de la fractura propia del robo, admitía un concurso real de delitos entre el robo y los daños al patrimonio histórico.

76 En este sentido, CORTÉS BECHIARELLI, E.: "Función social", cit., pp. 64-65; GARCÍA CALDERÓN, J. M.: "La relación", cit., p. 81; OTERO GONZÁLEZ, P.: "Protección penal", cit., p. 348. Afirmaba que esta relación concursal era de naturaleza ideal "cuando la lesión de aquel bien jurídico [n. de la a., el patrimonio cultural] se produzca con la mera remoción o extracción de su ubicación originaria de los objetos sustraídos, como consecuencia inherente a su apoderamiento", TASENDE CALVO, J. J.: "Los hurtos cualificados", cit., p. 26. Condena por apropiación indebida del art. 253 último inciso $\mathrm{CP}$ en concurso ideal con un delito de daños del art. $323 \mathrm{CP}$ la SAP de Toledo (Sección 2a) 84/2007, de 4 de diciembre (ARP 2008\167), en un caso de uso de detector de metales en dos necrópolis, no incluidas en el inventario arqueológico de la región, para extraer piezas que luego se vendieron.

77 Así, NÚÑEZ SÁNCHEZ, A. M.: "El expolio de yacimientos arqueológicos", en AA.VV.: La lucha contra el tráfico ilícito de bienes culturales, Madrid, 2006, p. 183. También era la posición mayoritaria en la jurispruden- 
si el sujeto se apoderaba de la cosa con el objetivo único de su destrucción, que llevaba a cabo, algunos entendían que solo cabía aplicar el delito de daños al patrimonio histórico (art. 323 CP en su redacción anterior a la reforma de 2015) ${ }^{79}$, mientras que otros optaban por el concurso real de delitos entre los daños al patrimonio histórico y el subtipo agravado de hurto o robo con fuerza en las cosas, según las circunstancias del caso $^{80}$. La aparición del delito de expolio no ha aclarado este confuso panorama, como veremos a continuación.

\section{5. ¿Una oportunidad perdida? EI delito de expolio}

Pese a las vacilaciones doctrinales y jurisprudenciales sobre los aspectos analizados en el apartado anterior, que dificultaban la protección de los yacimientos arqueológicos, hubo que esperar a la reforma operada por la LO 1/2015, de 30 de marzo, para que se introdujera una figura delictiva dedicada a castigar específicamente el expolio de bienes de yacimientos arqueológicos. Se trata del art. 323.1 CP, que lo hace en los siguientes términos: "Será castigado con la pena de prisión de seis meses a tres años o multa de doce a veinticuatro meses el que cause daños en bienes de valor histórico, artístico, científico, cultural o monumental, o en yacimientos arqueológicos, terrestres o subacuáticos. Con la misma pena se castigarán los actos de expolio en estos últimos". Por cierto, sin explicación alguna en el Preámbulo de la ley por parte del legislador.

Tampoco se preocupó el legislador por definir en qué consisten los "actos de expolio", siendo de esperar los proble-

cia. Vid. las SSAP de Lleida (Sección 1ª) 138/2019, de 20 de marzo (JUR 2019\152924), de Zaragoza (Sección 6 ${ }^{\text {a) }}$ 199/2018, de 16 de julio (ARP 2018\1199) y de Toledo (Sección $2^{\mathrm{a}}$ ) 84/2007, de 4 de diciembre (ARP 2008\167), y la SJP núm. 2 de Cáceres de 29 de octubre de 2014.

78 Por ejemplo, RENART GARCÍA, F.: El delito, cit., p. 466.

79 Cfr. RENART GARCÍA, F.: El delito, cit., pp. 465-466.

80 Cfr. RUFINO RUS, J.: "La protección”, cit., p. 65. 
mas interpretativos y aplicativos que han surgido ${ }^{81}$. En efecto, el término "expolio" admite una variedad de acepciones ${ }^{82}$. La expoliación, que no el expolio, se define en la Ley 16/1985 en los siguientes términos: "A los efectos de la presente Ley se entiende por expoliación toda acción u omisión que ponga en peligro de pérdida o destrucción todos o alguno de los valores de los bienes que integran el Patrimonio Histórico Español, o perturbe el cumplimiento de su función social..." (art. 4 LPHE) $)^{83}$. Así definida, la expoliación parece coincidir con una tentativa (se habla de puesta en peligro) de la conducta típica de daños ("pérdida o destrucción"), a la que se añade cualquier conducta que afecte negativamente el cumplimiento de la función social de los bienes culturales. Esta cláusula permitiría incluir el apoderamiento, pero también la exportación sin autorización y, en general, el incumplimiento por parte de los propietarios o de los titulares de derechos reales o los poseedores de los bienes de las obligaciones contenidas en los arts. 13, 26.2, 4 y 6, 28, 35.3, 36.1 y $2,38.1,39,44,51.2$ y 52.1 y 3 LPHE: entre otras, permitir y facilitar su inspección por parte de los Organismos competentes, su estudio a los investigadores, previa solicitud razonada de estos, y su visita pública; recabar el examen de los bienes, así como las informaciones pertinentes, para su inclusión en el Inventario General; comunicar a la Administración competente la existencia de estos objetos, antes de proceder a su venta o transmisión a terceros; permitir a la Administración inspeccionar su conservación; permitir su estudio a los investigadores, previa solicitud razonada, y a prestarlos, con las debidas garantías, a exposiciones temporales que se organicen; prestar su colabora-

81 Ya los anunciaba GUISASOLA LERMA, C.: "Evolución”, cit., p. 80.

82 Vid. al respecto, entre otros, TERREROS ANDRÉU, C.: "El expolio de Patrimonio Cultural: problemas de conceptualización jurídica", en Revista Electrónica de Patrimonio Histórico, núm. 14, junio 2014, pp. 60-97.

83 Sobre esta definición desde el punto de vista jurídico-administrativo, vid. BERMEJO LATRE, J. L.: "La indeterminación y amplitud del concepto de expolio del Patrimonio Cultural", en Patrimonio Cultural y Derecho, núm. 20, 2016, pp. 315 ss. 
ción en la ejecución de los Planes Nacionales de Información; conservarlos, mantenerlos y custodiarlos, etc...

Es obvia la falta de taxatividad de la definición administrativa de expoliación, que además es aplicable solo "a los efectos" de la Ley 16/1985 ${ }^{84}$. En mi opinión, cabe pensar que no tendría sentido añadir al delito de daños ya existente una conducta, la de expolio, que castigaría con la misma pena de los daños la tentativa y la consumación de una conducta igualmente constitutiva de daños. Además, falta en esa definición la variable de la propiedad y posesión de los bienes, cuando lo cierto es que la alteración de esas situaciones es inherente al concepto pre-jurídico de expolio. En efecto, expoliar se define en el Diccionario de la Lengua Española como "despojar con violencia o iniquidad". "Despojar" significa "privar a alguien de lo que goza y tiene, desposeerlo de ello con violencia", esto es, apoderarse del bien. Dado que en la mayor parte de los casos que nos ocupan no hay violencia, solo queda la "iniquidad", que significa "maldad, injusticia grande". Y sin duda hay injusticia grande cuando el apoderamiento, el acto de despojo, afecta al valor cultural objetivo que dota de unidad al conjunto arqueológico, más allá tanto del interés específico del bien en particular (histórico, artístico, etnográfico...), como de su valor material cuantificable en dinero: cuando el apoderamiento del bien y la consiguiente descontextualización de la ubicación original afectan, en suma,

84 Entienden que no se puede completar el término "expolio" del Código Penal con la definición de "expoliación" de la Ley 16/1985, entre otros, NÚÑEZ SÁNCHEZ, A.: "La nueva regulación penal", cit., pp. 165 ss.; VERCHER NOGUERA, A.: "El expolio de bienes de patrimonio histórico o la descontextualización penal del entorno arqueológico", en Diario La Ley, núm. 9151, 5 de marzo de 2018, pp. 5-6. Por el contrario, afirman que "debe completarse" la definición de expolio con lo previsto en el art. 4 LPHE, GUISASOLA LERMA, C.: "Delitos sobre el patrimonio histórico", cit., p. 1003, si bien reconoce que es un concepto "indeterminado y amplio", de forma que "no todo caso de expoliación en términos administrativos, podrá ser penalmente relevante", en "Delitos contra bienes culturales", cit., pp. 9-10; OTERO GONZÁLEZ, P.: "Protección penal", cit., p. 346; de la misma autora: "El delito doloso", cit., pp. 1196-1197; RODRÍGUEZ MORO, L.: "Críticas", cit., p. 94. 
al cumplimiento de su función social ${ }^{85}$. El Tribunal Constitucional ya ha tenido ocasión de señalar que la Ley 16/1985 "llama perturbación del cumplimiento de su función social a la privación del destino y utilidad general que es propio de cada uno de los bienes, aunque materialmente el bien mismo permanezca" (STC 17/1991, de 31 de enero [RTC 1991, 17], FJ $7^{\circ}$ ), es decir, aunque el bien no se haya destruido ni perdido. Por tanto, es posible entender que el expolio abarca tanto el apoderamiento como la afectación a la función social del concreto objeto expoliado, derivada de la pérdida del contexto arqueológico causada por la deslocalización ${ }^{86}$.

Con esta interpretación deberían solucionarse los problemas concursales que se plantean a la hora de castigar el apoderamiento de bienes encontrados en yacimientos arqueológicos. Entendida como una forma de apoderamiento, la introducción de la conducta de expolio entre los delitos contra el patrimonio histórico debería borrar de un plumazo los concursos de delitos con las infracciones contra el patrimonio agravadas por el valor científico, histórico, etc. del bien, pero también con los delitos de malversación de caudales públicos -recuérdese que estamos analizando la conducta del descubridor, no de otros sujetos. Un

85 En este sentido, entre otros, BERMEJO LATRE, J. L.: "La indeterminación”, cit., pp. 319-320.

86 Así, entre otros, ALEGRE ÁVILA, J.: "Patrimonio histórico y expoliación: variaciones y paradojas", en Revista Española de Derecho Administrativo, núm. 189, 2018, pp. 241-260; CUESTA AGUADO, P. de la: "La reforma", cit., pp. 648-650. Entienden que el expolio solo abarca el saqueo o latrocinio de los bienes, complementando así el delito de daños, MUÑOZ CUESTA, J./ RUIZ DE ERENCHUN ARTECHE, E.: Cuestiones prácticas sobre la reforma penal de 2015, Cizur Menor, 2015, p. 204. Hablan de apoderamiento JAÉN VALLEJO, M./ PERRINO PÉREZ, A. L.: La reforma penal de 2015, Madrid, 2015, p. 153. Vid. también la SAP de Lleida (Sección $1^{\text {a }}$ ) 138/2019, de 20 de marzo (JUR 2019 \152924), comentada por ANTÓN Y ABAJO, A.: "El delito de expolio", cit. Esta sentencia entiende que el expolio incluye el apoderamiento y la pérdida de información o de conocimiento que podía derivarse del estudio del lugar en el que se produjo el hallazgo, pero que el menoscabo o destrozo del yacimiento exigiría un concurso de delitos con los daños al patrimonio histórico. 
sector de la doctrina se decanta a favor de la apreciación de un concurso aparente de leyes penales, que se resolvería por aplicación del principio de especialidad a favor de los subtipos agravados de los delitos contra el patrimonio ${ }^{87}$ o bien del expolio ${ }^{88}$, mientras que otro sector habla de consunción, que se resolvería para unos a favor de los subtipos agravados ${ }^{89} \mathrm{y}$ para otros a favor del expolio ${ }^{90}$. También se menciona el principio de alternatividad como regla de solución, a resolver a favor del delito que resulte más gravemente penado. ¿Qué regla es aplicable? Por supuesto, la respuesta depende de la posición adoptada acerca de lo que abarca la conducta de expolio. En mi opinión -y, por tanto, desde la perspectiva de que el expolio abarca el apoderamiento y la pérdida del contexto arqueológico del bien -, la regla aplicable no es la especialidad. En el concurso aparente de leyes penales se trata de una especialidad puramente lógica: se aplica cuando entre las leyes en conflicto existe una relación de género a especie. El expolio no es un delito de apoderamiento patrimonial -como el hurto, el robo o la malversación- al que se añade un elemento que lo caracteriza frente al género -elemento que podría ser el daño causado por su separación del contexto arqueológico. Antes bien, uno y los otros son delitos pertenecientes a familias delictivas completamente distintas, con diferente estructura y bien jurídico protegido. Sin embargo, no es esta la perspectiva más importante en lo que se refiere a la resolución del concurso aparente de leyes penales, puesto que lo decisivo en este ámbito no es el solapamiento total o parcial de los hechos subyacentes susceptibles de ser incluidos lógicamente en

87 Así, RUFINO RUS, J.: "La tutela", cit., p. 503.

88 Así, GUISASOLA LERMA, C.: "Delitos contra bienes culturales", cit., p. 17.

89 Cfr. CUESTA AGUADO, P. de la: "La reforma", cit., p. 651.

90 Cfr. RODRÍGUEZ MORO, L.: "Críticas", cit., p. 96, alegando que el expolio es el precepto más amplio, al incluir apoderamiento y daño, que absorbe las infracciones consumidas en aquellos, los apoderamientos, aunque también se plantea si no sería más procedente apreciar un concurso de delitos entre el expolio y los tipos básicos de hurto, robo y apropiación indebida, "para no valorar el valor histórico y cultural de los bienes por partida doble". 
el tenor de los tipos convergentes, sino el solapamiento del desvalor que representan ${ }^{91}$. Hemos de analizar, por tanto, si el solapamiento de injustos es total, de modo que el desvalor del tipo general no solo esté enteramente cubierto por el tipo especial, sino que además este suponga la concreción de un plus o minus, bien de injusto o de culpabilidad, en relación con determinados hechos (species) del género representado por el tipo más amplio. "Se trata de formular un juicio hipotético negativo, en el que se suprima mentalmente la existencia del delito específico. Cuando suceda entonces que todo hecho sin excepción de los allí contemplados es susceptible de ser calificado con arreglo al precepto general, ha de afirmarse la relación de especialidad"92. Pues bien, suprimido mentalmente el delito de expolio, los hechos allí contemplados no son subsumibles en su totalidad ni en la malversación de caudales públicos, ni en los delitos contra el patrimonio, en su caso agravados por el valor artístico, histórico, cultural o científico del bien, en algún supuesto en concurso con el delito de daños sobre el patrimonio histórico por los causados en el yacimiento. En el expolio se castigan conductas de apoderamiento que no encajan en los delitos contra el patrimonio ni en la malversación ${ }^{93}$ : en concreto, el apoderamiento de bienes encontrados en yacimientos que, careciendo de valor económico, tampoco tienen por sí mismos un valor artístico, histórico, cultural o científico significativo, sino únicamente en tanto que, analizados con metodología arqueológica, ofrecen información sobre el yacimiento ${ }^{94}$. No es tanto que el expolio sea una suerte

91 Cfr. GARCÍA ALBERO, R.: "Non bis in idem" material y concurso de leyes penales, Barcelona, 1995, p. 181.

92 GARCÍA ALBERO, R.: "Non bis in idem”, cit., p. 322.

93 Así, MUÑOZ CONDE, F.: Derecho Penal. Parte especial, $22^{\mathrm{a}}$ ed. Valencia, 2019, pp. 530-531, cuando señala que habrá que incluir en el concepto de expolio "conductas que no se puedan considerar daños en sentido estricto, pero tampoco meras sustracciones o apropiaciones indebidas, que pueden castigarse aplicando los tipos cualificados de los respectivos delitos contra el patrimonio".

94 Así, CUESTA AGUADO, P. de la: "La reforma”, cit., pp. 649-650; RODRÍGUEZ MORO, L.: "Críticas”, cit., p. 96. 
de "cláusula de cierre en una tipificación residual para evitar supuestos de impunidad"95, cuanto que extiende el ámbito del apoderamiento penalmente relevante a objetos carentes de valor económico. También permite sancionar, en mi opinión, aquellas actuaciones dirigidas al apoderamiento que ponen en peligro de pérdida o destrucción todos o alguno de los bienes encontrados en el yacimiento, o que perturban el cumplimiento de su función social, en consonancia con la definición administrativa de expoliación ${ }^{96}$ : prospecciones, excavaciones y búsquedas no autorizadas, con independencia de que se haya obtenido o no la disponibilidad sobre el bien, entendida en los términos de los delitos de apoderamiento patrimonial ${ }^{97}$.

Tampoco hay relación de subsidiariedad expresa o tácita entre los preceptos concurrentes. Un precepto está en relación de subsidiariedad cuando debe ser aplicado solo en defecto de otro, configurándose como un tipo de recogida para el caso de que no resulte aplicable el tipo principal ${ }^{98}$. En el caso que nos ocupa, no hay un mandato legal que produzca el desplazamiento de la ley subsidiaria. Pero tampoco hay subsidiariedad tácita: entre los preceptos concurrentes no hay una relación minus-maius en lo que respecta a las formas de agresión a un mismo bien jurídico. Por último, no es posible afirmar que uno de los preceptos contemple de modo total el desvalor que el ordenamiento jurídico atribuye a la conducta, debiendo prevalecer sobre el que lo contempla solo de manera parcial.

95 Como propone NÚÑEZ SÁNCHEZ, A.: "La nueva regulación penal”, cit., p. 196.

96 En este sentido, NÚÑEZ SÁNCHEZ, A.: "La nueva regulación penal", cit., p. 196; parece que también RODRÍGUEZ MORO, L.: "Críticas", cit., p. 92. De lege ferenda, OTERO GONZÁLEZ, P.: "Protección penal”, cit., pp. 348-349; de la misma autora: "El delito doloso", cit., pp. 1196-1197.

97 Considera expolio "conductas como las de realizar excavaciones ilegales" MUÑOZ CONDE, F.: Parte especial, $22^{\mathrm{a}}$ ed. cit., p. 531, que añade, cosa que yo no hago, la perpetración de actos vandálicos en los yacimientos. En contra de incluir conductas de apoderamiento, por entender que "para que exista un expolio es preciso que el sujeto activo haya obtenido la disponibilidad sobre la cosa mueble", CUESTA AGUADO, P. de la: "La reforma", cit., p. 649. 
Dado que no hay relación de especialidad, ni de subsidiariedad expresa o tácita, ni uno de los preceptos es más amplio o complejo que el otro, el concurso de leyes se ha de resolver por alternatividad (art. 8.4 CP), a favor del precepto que establezca la pena más elevada. Pero no es fácil determinar cuál es. La pena del hurto de bienes de cuantía inferior a 400 euros es multa de uno a tres meses, y la del tipo básico de hurto es prisión de seis a dieciocho meses. Este es el marco de la comparación cuando estamos ante objetos carentes de valor económico en sí mismos considerados, pero relevantes para la investigación arqueológica. Piénsese en fragmentos de vasijas, restos de comida o vestuario, semillas... En este caso se aplica el delito de expolio, que contempla penas más graves ${ }^{99}$. Ciertamente, la aplicación preferente del expolio tiene el inconvenientes de que no es posible apreciar un delito de receptación cuando el bien encontrado sea recibido, adquirido u ocultado por un tercero, incluso para traficar con él, dado que el expolio no es un delito contra el patrimonio o el orden socioeconómico, como exige el art. 298 CP. Frente a ello, cabe señalar que es posible apreciar, en su caso, el delito de blanqueo ${ }^{100}$, castigado con penas más elevadas. Tratándose de bienes susceptibles de valoración económica, y dotados además de valor histórico, artístico, científico o cultural en sí mismos, hay que aplicar sea el hurto agravado, sea la malversación, que contemplan penas más elevadas: para el expolio se prevé prisión de seis meses a tres años o multa de doce a veinticuatro meses, frente a prisión de uno a tres años para el subtipo

98 Cfr. GARCÍA ALBERO, R.: “Non bis in idem”, cit., pp. 333 ss.

99 En esta línea, vid. CUESTA AGUADO, P. de la: "La reforma", cit., p. 651.

100 Como propone OTERO GONZÁLEZ, P.: "Protección penal”, cit., p. 350; de la misma autora, "El delito doloso", cit., p. 1197. Sobre la relación entre el blanqueo y la compraventa de antigüedades, vid. ampliamente ROMA VALDÉS, A.: "Mercado de arte y antigüedades y prevención delictiva", en Cuadernos de prehistoria y arqueología de la Universidad de Granada, núm. 25, 2015, pp. 145-165. En la jurisprudencia se ha aplicado el blanqueo incluso en casos de venta de efectos sustraídos en un yacimiento en que el delito antecedente era un hurto agravado. Vid. la SAP de Zaragoza (Sección 6) 199/2018, de 16 de julio (ARP 2018\1199). 
agravado de hurto, y prisión de dos a seis años, inhabilitación especial para cargo o empleo público y para el ejercicio del derecho de sufragio pasivo por tiempo de seis a diez años previstas para el tipo básico de malversación. Solo si se hubieran causado daños de especial gravedad o que hubieran afectado a bienes cuyo valor histórico, artístico, científico, cultural o monumental fuera especialmente relevante sería aplicable el expolio en lugar del hurto, pues el subtipo agravado de hurto tiene penas más bajas. Si se opta por la malversación, este es siempre el delito más penado y, por tanto, de aplicación preferente.

¿Castiga el expolio la causación de daños en el yacimiento, conjuntamente con el apoderamiento de los bienes que en él se encuentran? ¿Es el expolio solo una modalidad de daños? Un sector doctrinal entiende que el delito de expolio abarca únicamente los daños causados en el yacimiento ${ }^{101}$. A esta interpretación se opone que el expolio se castigue con pena idéntica a los daños sobre el patrimonio histórico, lo que no tiene mucho sentido si el expolio debe recoger, además de los daños, el desvalor propio del apoderamiento ${ }^{102}$, pero tampoco si el expolio solo abarca los daños, porque sería reiterar lo ya tipificado en el primer inciso del mismo precepto ${ }^{103}$, sin que se apreciaran aquí lagunas de punibilidad ${ }^{104}$. Otros autores entienden que los daños

101 En este sentido, A favor de que el expolio puede verse como una modalidad de "daño", CORCOY BIDASOLO, M.: “Art. 323”, en CORCOY BIDASOLO, M./ MIR PUIG, S. (Dirs.): Comentarios al Código Penal. Reforma LO 1/2015 y LO 2/2015, Valencia, 2015, p. 1164; GARCÍA CALDERÓN, J. M.: La defensa penal, cit., p. 280; del mismo autor: "Los delitos", cit., pp. 743 y 753-759, donde incluye en el concepto de expolio los daños materiales e inmateriales sufridos por el yacimiento y el apoderamiento o sustracción de aquellas piezas arqueológicas descubiertas, pero luego matiza esa afirmación; GUISASOLA LERMA, C.: "Delitos contra bienes culturales", cit., p. 16; RUFINO RUS, J.: "La tutela", cit., p. 503; VERCHER NOGUERA, A.: "El expolio", cit., p. 4.

102 En este sentido, entre otros, NÚÑEZ SÁNCHEZ, A.: "La nueva regulación penal", cit., p. 195.

103 Así, YÁÑEZ VEGA, A.: “Actividades ilícitas”, cit., pp. 14-15.

104 En la jurisprudencia anterior a 2015 se castigaban pacíficamente los daños causados en el yacimiento, tanto los consistentes en la destrucción o 
materiales, esto es, la destrucción o menoscabo de los bienes muebles e inmuebles que se encuentran en el yacimiento, se castigan en el primer párrafo del apartado $1^{\circ}$, y los daños derivados de la pérdida de contexto de las piezas, en el expolio ${ }^{105}$. En mi opinión, como se ha visto, el expolio no abarca el detrimento, deterioro o menoscabo de la integridad física del yacimiento ocasionado por la deslocalización del bien, ni tampoco la destrucción o menoscabo de los otros bienes muebles e inmuebles que se encuentran en el yacimiento, resultados respecto de los cuales habrá que aplicar el correspondiente concurso de delitos con los daños al patrimonio histórico.

\section{Conclusiones}

Si queremos una efectiva protección de los bienes que se encuentran en yacimientos arqueológicos debemos articular un tipo penal que permita abarcar tanto el perjuicio patrimonial que se deriva de su apoderamiento como el daño que se causa al patrimonio histórico al separar la pieza de su entorno. El delito de expolio no cumple adecuadamente esta función. En la doctrina no está claro si es un delito de daños o de apoderamien-

menoscabo de estructuras u objetos como los que solo ocasionaban una pérdida de información arqueológica, como delito de daños al patrimonio histórico. Por ejemplo, se consideraron daños al patrimonio histórico los sondeos y hoyos en yacimiento arqueológico catalogado que causan daños de carácter secuencial y estratigráfico que impiden la interpretación científica del yacimiento. Vid. la SJP núm. 2 de Ciudad Real 337/2002, de 18 de diciembre (ARP 2003\67). También la realización de agujeros en un yacimiento, llegando a fracturar cerámicas y provocar afecciones a las estructuras arqueológicas emergentes y pérdidas de información en general. Vid. la SAP de Málaga (Sección 1ª) 454/2009, de 21 de julio (ARP 2011 5599). Y la realización de excavaciones en el suelo del interior de una torre-fortaleza en ruinas, causando una pérdida de información histórica difícil de evaluar. Vid. la SAP de Cáceres (Sección 2a) 128/2008, de 11 de noviembre (JUR 2009\35028).

105 En este sentido, CUESTAAGUADO, P. de la: "La reforma", cit., p. 650; MARTÍNEZ-BUJÁN PÉREZ, C., Derecho penal económico y de la empresa. Parte especial, $5^{\text {a }}$ ed. Valencia, 2015, p. 933; el mismo autor en VIVES ANTÓN, T. S., y otros: Derecho Penal. Parte Especial, 6 ed. Valencia, 2019, p. 578. 
to, hasta el punto que, actualmente, sigue defendiéndose por un sector doctrinal que en los casos que nos ocupan es aplicable la apropiación indebida propia del art. $253.1 \mathrm{CP}^{106}$, mientras que otro opta por la apropiación de cosa mueble ajena del art. 254 $\mathrm{CP}^{107}$. Se castiga igual que el delito de daños, pero su tipo básico está menos penado que los delitos de apoderamiento patrimonial agravados por el valor histórico, artístico, cultural o científico. No resuelve los problemas concursales existentes ${ }^{108}$, sino que introduce un nuevo factor que los complica todavía más ${ }^{109}$. Sin embargo, tiene al menos un aspecto positivo: da respuesta, en mi opinión, al importante sector doctrinal que venía reclamando desde hace años una regulación del expolio arqueológico que permitiera el castigo de las etapas previas al apoderamiento, como son las excavaciones y remociones de tierra ilegales ${ }^{110}$.

106 En este sentido, JAÉN VALLEJO, M./ PERRINO PÉREZ, A. L.: La reforma penal de 2015, cit., p. 153.

107 Defiende que el saqueo de yacimientos debe enmarcarse en la apropiación indebida de cosa mueble ajena, por todos, GARCÍA CALDERÓN, J. M.: La defensa penal, cit., p. 238.

108 Vid., por ejemplo, todas las posibilidades concursales que ofrece GARCÍA CALDERÓN, J. M.: "Los delitos", cit., pp. 758-759.

109 En general, la doctrina se ha mostrado muy crítica. Afirma OTERO GONZÁLEZ, P.: "Protección penal", cit., p. 366, que la regulación del expolio se ha llevado a cabo con defectos de técnica legislativa que "en ocasiones empeoran la interpretación sistemática con respecto a la legislación anterior". En sentido similar, señala NÚÑEZ SÁNCHEZ, A. M.: "La nueva regulación penal", cit., p. 171, que si bien algunos aspectos de la reforma "resuelven ciertas problemáticas que se habían evidenciado desde la aprobación del Código Penal, dejan abiertas otras muchas e incluso innecesariamente abren algunas nuevas". En la misma línea, apunta RODRÍGUEZ MORO, L.: "Críticas", cit., p. 96, que se aprecia "un absoluto caos interpretativo sobre el tratamiento y aplicación de esta conducta al no haberse conectado con el contenido de estos otros preceptos preexistentes". Por su parte, GARCÍA CALDERÓN, J. M.: La defensa penal, cit., p. 191, pone de manifiesto que la reforma es "caótica desde una perspectiva sistemática e insegura desde una perspectiva criminológica"; del mismo autor: "Los delitos", cit., pp. 754-756. Además, entre otros, CUESTA AGUADO, P. de la: "La reforma", cit., pp. 651-652 y 654; GUISASOLA LERMA, C.: "Delitos contra bienes culturales", cit., p. 15; SUÁREZ LÓPEZ, J. M.: “Artículo 323”, en GÓMEZ TOMILlO, M. (Dir.): Comentarios prácticos al Código Penal. Tomo IV, Cizur Menor, 2015, p. 88. 
Los subtipos agravados de los delitos contra el patrimonio, por su parte, protegen en primera línea el patrimonio, y solo secundariamente tienen en cuenta la especial protección que merecen los bienes culturales. En ellos prevalece el interés individual frente al colectivo, distanciándose de la función social de los bienes culturales ${ }^{111}$. En su condición de subtipos agravados, es necesario para su aplicación que se den los requisitos de los tipos básicos respectivos ${ }^{112}$. Solo una vez comprobada su presencia cabe aplicar el subtipo agravado cuando, además, se constate que concurre el valor artístico, histórico, cultural o científico del bien en cuestión. El fundamento de la agravación es, pues, que se afecta a otro bien jurídico además del patrimonio, de naturaleza colectiva, como es el patrimonio histórico. Se trata, por tanto, de delitos pluriofensivos, en los que la afectación de otro bien jurídico supone un incremento del contenido de injusto ${ }^{113}$. ¿Hay que eliminarlos? No, en mi opinión. Es perfectamente posible sustraer los bienes culturales a su legítimo titular (la Administración o un particular) o apropiarse de ellos sin afectar a los yacimientos en los que, en su caso, fueron encontrados. En ese caso no cabría aplicar el expolio, sino únicamente el subtipo agravado del delito patrimonial correspondiente. Tampoco es aplicable

110 Vid. por ejemplo, GUISASOLA LERMA, C.: "Delitos contra el patrimonio histórico", cit., p. 891; OTERO GONZÁLEZ, P.: "Protección penal", cit., pp. 348-349; ROMA VALDÉS, A.: "El expolio del patrimonio arqueológico español”, en Patrimonio Cultural y Derecho, núm. 6, 2002, pp. 127-147; del mismo autor: La aplicación, cit., p. 75.

111 Como señalan, críticamente, por todos, GARCÍA CALDERÓN, J. M.: La defensa penal, cit., p. 219; RENART GARCÍA, F.: El delito, cit., p. 177; SALINERO ALONSO, C.: La protección, cit., p. 179. De ello es ejemplo que pueda aplicárseles la causa de exclusión de la pena prevista en el art. $268 \mathrm{CP}$, aplicable a determinados parientes por los delitos patrimoniales que se causaren entre sí, siempre que no concurra violencia o intimidación, o abuso de vulnerabilidad de la víctima. La impunidad no tiene sentido si también se protege en los subtipos agravados un interés colectivo. En este sentido, cfr. GARCÍA CALDERÓN, J. M.: op. cit., pp. 233-234.

112 Cfr. PÉREZ ALONSO, E. J.: "Delitos”, cit., marginal 620.

113 A ello apunta, entre otros, PÉREZ MANZANO en BAJO FERNÁNDEZ, M. (Dir.): Compendio (Parte Especial) II, cit., p. 361. Vid. también GOYENA HUERTA, J.: "Hurto", cit., p. 69. 
el expolio cuando se sustraen bienes culturales no procedentes de yacimientos. Piénsese, por ejemplo, en el hurto de bienes de la Iglesia, muy a menudo bienes de gran valor, situados en lugares de fácil acceso y escasa protección ${ }^{114}$, o de una colección arqueológica en manos privadas. Por su parte, el ámbito específico de aplicación del subtipo agravado de la apropiación indebida de cosa perdida que nos ocupa se limita, de esta forma, a aquellos objetos de valor artístico, histórico, cultural o científico que, siendo de titularidad privada o pública, ya fuera del yacimiento, son perdidos por su dueño y encontrados por otra persona que incumple su obligación de devolverlos a su anterior poseedor, si es conocido, o consignarlos ante las autoridades, de no serlo.

\section{Bibliografía}

ALEGRE ÁVILA, J. M.: Evolución y régimen jurídico del patrimonio histórico. Volumen II, Madrid, 1994.

"El patrimonio arqueológico: aspectos de su régimen jurídico", en Patrimonio Cultural y Derecho, núm. 1, 1997, pp. 121-130.

$114 \mathrm{Se}$ encuentran numerosas sustracciones de este tipo en la jurisprudencia. Entre otras, vid. las SSTS 747/2015 de 19 de noviembre (RJ 2015\6502), por la que se condena como autor de un delito continuado de robo con fuerza en las cosas con la agravante por razón de la cuantía del valor de lo sustraído y por la del valor histórico y artístico del Códice Calixtino; y 189/2003 de 12 de febrero (RJ 2003\1087), en un caso descrito como de expolio de los fondos bibliográficos de la Biblioteca Diocesana de Zamora, entre ellos diez incunables, intentando camuflar bajo compra los pagos efectuados al responsable de la biblioteca que, más que verdadero precio de compra de los libros, eran retribución por su colaboración en la sustracción. También las SSAP de Lugo (Sección 1 ${ }^{a}$ ) 193/2005 de 17 de junio (JUR 2005\176186); Teruel (Sección Única) 28/2003 de 16 de septiembre (JUR 2003\242956); Soria (Sección $1^{\text {a }}$ ) 60/2003 de 22 de octubre (JUR 2004\42085); Sevilla (Sección $7^{\mathrm{a}}$ ) 70/2002 de 11 de diciembre (JUR 2003\47523); Zamora (Sección Única) 4/2000 de 24 de febrero (ARP 2000\1957). 
“El patrimonio histórico español: régimen jurídico de la propiedad histórica", en Anuario de la Facultad de Derecho de la Universidad Autónoma de Madrid, núm. 19, 2015, pp. 213-251.

"Patrimonio histórico y expoliación: variación y paradojas", en Revista Española de Derecho Administrativo, núm. 189, 2018, pp. 241-260.

ALMELA VICH, C.: "Delitos sobre el patrimonio histórico", en Actualidad Penal, 2000-3, marginales 871-890.

ANTÓN Y ABAJO, A.: "El delito de expolio y su problemática concursal (Un caso paradigmático: la SAP Lleida, Sección 1a, de 20 de marzo de 2019)", en Diario La Ley, núm. 9508, 29 de octubre de 2019.

ARIAS EIBE, M. J.: El patrimonio cultural. La nueva protección en los arts. 321 a 324 del Código penal de 1995, Granada, 2001.

BAJO FERNÁNDEZ, M.: Manual de Derecho penal. Parte especial (Delitos patrimoniales y económicos), Madrid, 1987.

“Artículo 250”, en COBO DEL ROSAL, M. (Dir.): Comentarios al Código penal. Tomo VIII. Delitos contra el patrimonio y contra el orden socioeconómico (Artículos 234 a 272), Madrid, 1999, pp. 317-353.

BAJO FERNÁNDEZ, M. (Dir.): Compendio de Derecho Penal (Parte Especial), II, Madrid, 1998.

BAJO FERNÁNDEZ, M./ BACIGALUPO, S.: Derecho Penal Económico, Madrid, 2001.

BARCELONA LLOP, J.: "El dominio público arqueológico", en Revista de Administración Pública, núm. 151, 2000, pp. 133-166.

"Consideraciones sobre el régimen jurídico del patrimonio arqueológico", en FERNANDO PABLO, M. (Dir.): $\mathrm{Pa}$ trimonio cultural y nuevas tecnologías: entorno jurídico, Salamanca, 2012, pp. 265-299.

BELTRÁN BALLESTER, E.: El hurto de hallazgo (Protección penal de la propiedad perdida en la legislación española, histórica y actual), Valencia, 1979. 
BERMEJO LATRE, J. L.: "La indeterminación y amplitud del concepto de expolio del Patrimonio Cultural", en Patrimonio Cultural y Derecho, núm. 20, 2016, pp. 311-331.

BRAGADO CALVO, E.: El hallazgo. Doctrina, legislación y casos prácticos, Madrid, 1957.

CÁCERES RUIZ, L.: Delitos contra el Patrimonio Histórico. Sustracción de cosa propia a su utilidad cultural, Madrid, 2008.

CASTRO MORENO, A.: La malversación de caudales públicos en el Código Penal de 1995, Valencia, 2001.

CHOCLÁN MONTALVO, J. A.: El delito de estafa, $2^{\text {a }}$ ed. Barcelona, 2009.

CONDE-PUMPIDO FERREIRO, C.: Estafas, Valencia, 1997.

CORCOY BIDASOLO, M.: "Art. 323”, en CORCOY BIDASOLO, M./ MIR PUIG, S. (Dirs.): Comentarios al Código Penal. Reforma LO 1/2015 y LO 2/2015, Valencia, 2015, pp. 1163-1165.

CORTÉS BECHIARELLI, E.: "Función social y tutela penal del patrimonio arqueológico", en Revista Penal, núm. 13, 2004, pp. 47-66.

CUESTA AGUADO, M. P. de la: "La reforma de los delitos contra el patrimonio histórico. El delito de expolio", en QUINTERO OLIVARES, G. (Dir.): Comentario a la reforma penal de 2015, Cizur Menor, 2015, pp. 643-654.

DOMÍNGUEZ LUÍS, J. A., y otros: Delitos relativos a la ordenación del territorio y protección del patrimonio histórico, medio ambiente y contra la seguridad colectiva, Barcelona, 1999.

ENTRENA FABRÉ, R.: El delito de malversación, Valencia, 1999.

FARALDO CABANA, P.: "El delito de contrabando de bienes integrantes del patrimonio histórico español. Comentario al art. 2.1 e) de la Ley Orgánica 12/1995, de 12 de diciembre, de represión del contrabando", en SERRANO-PIEDECASAS FERNÁNDEZ, J. R./ DEMETRIO CRESPO, E. (Dirs.): El derecho penal económico y em- 
presarial ante los desafios de la sociedad mundial del riesgo, Madrid, 2010, pp. 223-258.

“La protección del Patrimonio Histórico en el Código Penal Militar", en Patrimonio Cultural y Derecho, núm. 15, 2011, pp. 193-216.

FERNÁNDEZ ALBOR, A.: "El patrimonio artístico y su protección penal", en AA.VV.: Estudios penales. Libro Homenaje al Prof. J. Antón Oneca, Salamanca, 1982, pp. 701-716.

FERNÁNDEZ APARICIO, J. M.: La protección penal del Patrimonio Histórico, Sevilla, 2004.

FERRER SAMA, A.: El delito de apropiación indebida, Murcia, 1944, pp. 405-488.

“Apropiación indebida”, en MASCAREÑAS, C. E. (Dir.): Nueva Enciclopedia Jurídica. Tomo II, Barcelona, 1983, pp. 754-777.

GALLEGO ANABITARTE, A.: “Arqueología y Derecho. Hallazgos, jurisprudencia, legislación, carta arqueológica y planeamiento", en Revista de Derecho Urbanístico y Medio Ambiente, núm. 200, 2003, pp. 41-134.

GALLEGO SOLER, J. I.: “Art. 252”, en CORCOY BIDASOLO, M./ MIR PUIG, S. (Dirs.): Comentarios al Código Penal. Reforma LO 1/2015 y LO 2/2015, Valencia, 2015, pp. 880-886.

“Art. 253”, en CORCOY BIDASOLO, M./ MIR PUIG, S. (Dirs.): Comentarios al Código Penal. Reforma LO 1/2015 y LO 2/2015, Valencia, 2015, pp. 886-891.

GARCÍA ALBERO, R.: "Non bis in idem" material y concurso de leyes penales, Barcelona, 1995.

GARCÍA ARÁN, M.: El delito de hurto, Valencia, 1998.

GARCÍA CALDERÓN, J. M.: "A protección penal do Patrimonio Histórico”, en Revista Xurídica Galega, núm. 16, 1997, pp. 15-36.

“La protección penal del patrimonio arqueológico", en $\mathrm{Pa}$ trimonio Cultural y Derecho, núm. 7, 2003, pp. 99-123. 
"La relación del patrimonio histórico con el derecho penal", en AA.VV.: La lucha contra el tráfico ilícito de bienes culturales, Madrid, 2006, pp. 67-86.

“Los delitos sobre el Patrimonio Histórico Español. Los daños dolosos a los bienes culturales (artículo 323 del Código Penal)", en MORILLAS CUEVA, L. (Dir.): Estudios sobre el Código Penal reformado (Leyes Orgánicas 1/2015 y 2/2015), Madrid, 2015, pp. 741-766.

_La defensa penal del patrimonio arqueológico, Madrid, 2016.

GARCÍA MAGNA, D.: "La protección penal frente al expolio del patrimonio cultural subacuático", en ÁLVAREZ GONZÁLEZ, E. M. (Dir.): Patrimonio arqueológico sumergido: una realidad desconocida, Málaga, 2009, pp. 135-174.

GIMENO LAHOZ, R./ CORBELLA HERREROS, T.: "Delitos contra la Administración Pública. Título XIX", en GANZENMÜLLER, C./ ESCUDERO, J. F./ FRIGOLA, J. (Coords.): Delitos contra la Administración pública; contra la Administración de justicia, y contra la Constitución, Barcelona, 1998, pp. 9-132.

GÓMEZ DE LIAÑO POLO, G.: Delitos contra el patrimonio cultural, especial estudio de contrabando de patrimonio histórico artístico, Doc. Núm. 12/06, Madrid, 2001, pp. 1-22.

GONZÁLEZ RUS, J. J.: "Puntos de partida de la protección penal del patrimonio histórico, cultural y artístico", en Anuario de Derecho Penal y Ciencias Penales, Tomo 48, Fasc. 1, 1995, pp. 33-56.

"Delitos contra el patrimonio y contra el orden socioeconómico (II)", en COBO DEL ROSAL, M. (Dir.): Derecho penal español. Parte especial, $2^{\mathrm{a}}$ ed. Madrid, 2005, pp. 453-467.

GOYENA HUERTA, J.: "Hurto", en MUÑOZ CUESTA, J. (Coord.): El hurto, el robo y el hurto y robo de uso de vehículos, Pamplona, 1998, pp. 15-94. 
GROIZARD Y GÓMEZ DE LA SERNA, A.: El Código Penal de 1870 concordado y comentado. Tomo VI, Salamanca, 1896.

GUISASOLA LERMA, C.: Delitos contra el patrimonio cultural. Artículos 321 a 324 del Código Penal, Valencia, 2001.

“Delitos contra el patrimonio histórico", en ÁLVAREZ GARCÍA, F. J. (Dir.): Estudio crítico sobre el anteproyecto de reforma penal de 2012, Valencia, 2013, pp. 887892.

“Delitos sobre el patrimonio histórico: artículo $323 \mathrm{del}$ CP”, en GONZÁLEZ CUSSAC, J. L. (Dir.): Comentarios al Código Penal de 2015, 2ª ed. Valencia, 2015, pp. 1001-1006.

"Evolución de los delitos del patrimonio histórico español en nuestro Código Penal, ayer y hoy", en AA.VV.: IV Encuentro Profesional sobre lucha contra el tráfico ilícito de bienes culturales. Regulación penal de la protección del patrimonio histórico español, Madrid, 2016, pp. 7383, disponible en la página web https://sede.educacion. gob.es/publiventa/iv-encuentro-profesional-sobre-luchacontra-el-trafico-ilicito-de-bienes-culturales-regulacionpenal-de-la-proteccion-del-patrimonio-historico-espanol/patrimonio-historico-artistico-legislacion/20824C

"Delitos contra bienes culturales: una aproximación al concepto de expolio en Derecho penal", en Revista General de Derecho Penal, núm. 27, 2017, pp. 1-28.

JAÉN VALLEJO, M./ PERRINO PÉREZ, A. L.: La reforma penal de 2015, Madrid, 2015.

JARAMILlO GARCÍA, A.: Novísimo Código Penal comentado y cotejado con el de 1870. Volumen II. Libros II y III. Artículos 215 al 858, Salamanca, 1929.

LÓPEZ BELTRÁN DE HEREDIA, C.: "El régimen jurídico del tesoro oculto después de la Ley 16/1985, del Patrimonio Histórico Español”, en BLASCO GASCÓ, F. de P., y otros (Coords.): Estudios jurídicos en homenaje 
a Vicente L. Montés Penadés. Tomo I, Valencia, 2011, pp. 1355-1379.

LÓPEZ BRAVO, C.: "Interrelación de las categorías legales de protección del Patrimonio Cultural en España", en PH: Boletín del Instituto Andaluz del Patrimonio Histórico, núm. 27, 1999 pp. 83-90. https://doi. org/10.33349/1999.27.806

LÓPEZ-REY Y ARROJO, M./ ÁLVAREZ VALDÉS, F.: El nuevo Código Penal, Madrid, 1933.

LORENZO SALGADO, J. M.: "Contrabando", en BOIX REIG, J. (Dir.): Diccionario de Derecho penal económico, Madrid, 2008, pp. 255-265.

MARTÍN DÍAZ, A.: "Dificultades de la instrucción y el enjuiciamiento de los delitos contra el patrimonio histórico", en PH: Boletín del Instituto Andaluz del Patrimonio Histórico, año 20, núm. 82, 2012, pp. 77-80. https://doi. org/10.33349/2012.82.3309

MARTÍNEZ-BUJÁN PÉREZ, C.: Derecho penal económico y de la empresa. Parte especial, $4^{\mathrm{a}}$ ed. Valencia, 2013.

-Derecho penal económico y de la empresa. Parte especial, $5^{\mathrm{a}}$ ed. Valencia, 2015.

_El delito de administración desleal de patrimonio ajeno, Valencia, 2016.

MARTÍNEZ DÍAZ, B.: "Análisis y propuestas sobre el expolio del Patrimonio Arqueológico", en Boletín del Museo Arqueológico Nacional, tomo XIV, núms. 1-2, 1996, pp. 187-194.

MARTÍNEZ DÍAZ, B./ QUEROL, M. A.: “La gestión del patrimonio arqueológico en las comunidades autónomas: balance y situación actual", en PH: Boletín del Instituto Andaluz del Patrimonio Histórico, núm. 48, 2004, pp. 101-109. https://doi.org/10.33349/2004.48.1727

MORALES PRATS, F./ MORALES GARCÍA, O.: “Art. 432”, en QUINTERO OLIVARES, G. (Dir.): Comentarios a la Parte Especial del Derecho Penal, Cizur Menor, 1996, pp. 1246-1251. 
MOREU BALLONGA, J. L.: "Artículo 351. Descubrimiento de tesoro oculto", en VALPUESTA FERNÁNDEZ, R., y otros (Dirs.): Código Civil comentado, Volumen 1, Cizur Menor, 2011, pp. 1422-1432.

MUÑOZ CONDE, F.: "El tráfico ilegal de obras de arte", en Estudios Penales y Criminológicos, Vol. XVI, 1993, pp. 395-422.

Derecho Penal. Parte especial, 22 ${ }^{\mathrm{a}}$ ed. Valencia, 2019.

MUÑOZ CUESTA, J.: "El delito de malversación”, en La Ley, 1996-5, pp. 1570-1573.

MUÑOZ CUESTA, J./ RUIZ DE ERENCHUN ARTECHE, E.: Cuestiones prácticas sobre la reforma penal de 2015, Cizur Menor, 2015.

NÚÑEZ SÁNCHEZ, A. M.: "El expolio de yacimientos arqueológicos", en AA.VV.: La lucha contra el tráfico ilícito de bienes culturales, Madrid, 2006, pp. 175-204, disponible en la página web https://sede.educacion.gob.es/publiventa/descarga.action?f_codigo_agc $=12946 \mathrm{C} \_19$

"La nueva regulación penal del delito de expolio de yacimientos arqueológicos", en GUISASOLA LERMA, C. (Dir.): Expolio de bienes culturales. Instrumentos legales frente al mismo, Valencia, 2018, pp. 165-198.

OROZCO PARDO, G./ PÉREZ ALONSO, E. J.: La tutela civil y penal del Patrimonio Histórico, cultural y artístico, Madrid, 1996.

ORTS BERENGUER, E.: "De la malversación", en VIVES ANTÓN, T. S. (Coord.): Comentarios al Código Penal de 1995. Volumen II (Arts. 234 a Disposiciones Finales), Valencia, 1996, pp. 1851-1861.

OTERO GONZÁLEZ, P.: "Protección penal de los daños al patrimonio histórico (tras la reforma del Código Penal operada por la LO 1/2015)", en Anuario de la Facultad de Derecho de la Universidad Autónoma de Madrid, núm. 19, 2015, pp. 325-370.

"El delito doloso de daños a bienes de valor cultural (artículo $323 \mathrm{CP}$ ) conforme a la LO 1/2015", en BACIGA- 
LUPO SAGGESE, S./ FEIJOO SÁNCHEZ, B./ ECHANO BASALDUA, J. I. (Coords.): Estudios de Derecho penal. Homenaje al profesor Miguel Bajo, Madrid, 2016, pp. 1189-1206.

OTERO GONZÁLEZ, P./ ÁLVAREZ GARCÍA, F. J.: "La protección penal del patrimonio cultural en la Constitución Española (presupuestos constitucionales de la protección penal del Patrimonio Histórico)", en Revista de Derecho Penal, núm. 35, 2012, pp. 35-65PANTALEÓN PRIETO, F.: “Art. 351”, en PAZ-ARES RODRÍGUEZ, C., y otros: Comentario del Código Civil. Tomo I, Madrid, 1991, pp. 985-989.

PÉREZ ALONSO, E.: "Los delitos contra el patrimonio histórico en el Código penal de 1995", en Actualidad Penal, 1998-2, marginales 611-642.

"El delito de contrabando de bienes culturales", en La Ley Penal, núm.52, año V, septiembre 2008, pp. 45-61.

QUINTANO RIPOLLÉS, A.: Comentarios al Código Penal. Vol. II, Madrid, 1946.

— Tratado de la parte especial del Derecho penal. Tomo II, Madrid, 1977.

QUINTERO OLIVARES, G.: "El hurto", en COBO DEL ROSAL, M. (Dir.): Comentarios a la legislación penal. Tomo V. Vol. 2, Madrid, 1985, pp. 1127-1156.

“Art. 235”, en QUINTERO OLIVARES, G. (Dir.): Comentarios a la Parte Especial del Derecho Penal, Cizur Menor, 1996, pp. 449-453.

QUINTERO OLIVARES, G./ MUÑOZ CONDE, F.: La reforma penal de 1983, Barcelona, 1983.

RENART GARCÍA, F.: El delito de daños al patrimonio cultural español. Análisis del art. 323 del Código penal de 1995, Granada, 2002.

"Aspectos sustantivos del delito de contrabando de bienes culturales", en Revista de Derecho Penal y Criminología, núm. 10. 2002, pp. 143-198. 
ROCA AGAPITO, L.: El delito de malversación de caudales públicos, Barcelona, 1999.

RODRÍGUEZ ARROCHA, B.: "El tesoro en la jurisprudencia española", en Anales de la Facultad de Derecho, núm. 24, 2007, pp. 195-202.

RODRÍGUEZ DEVESA, J. M./ SERRANO GÓMEZ, A.: Derecho Penal Español. Parte Especial, $18^{\mathrm{a}}$ ed. Madrid, 1995.

RODRÍGUEZ MORO, L.: "Críticas, incongruencias y dudas en la regulación penal de los delitos sobre el patrimonio histórico español antes y después de la reforma del Código Penal operada por la LO 1/2015, de 30 de marzo", en AA.VV.: IV Encuentro Profesional sobre lucha contra el tráfico ilícito de bienes culturales. Regulación penal de la protección del patrimonio histórico español, Madrid, 2016, pp. 84-100.

RODRÍGUEZ MOURULLO, G.: "El objeto de protección en los delitos contra el patrimonio histórico", en CARBONELL MATEU, J. C., y otros (Coords.): Estudios penales en homenaje al Profesor Cobo del Rosal, Madrid, 2005, pp. 775-785.

RODRÍGUEZ NÚÑEZ, A.: "Algunos problemas en la protección penal del patrimonio cultural", en Revista de Derecho Penal y Criminología, núm. 1 extraordinario, 2000, pp. 401-424.

RODRÍGUEZ RAMOS, L.: “Apropiación de la totalidad del tesoro oculto", en Cuadernos de Política Criminal, núm. 3, 1977, pp. 289-294.

“Apropiación de lo hallado”, en COBO DEL ROSAL, M. (Dir.): Comentarios a la legislación penal. Tomo V. Vol. 2, Madrid, 1985, pp. 1273-1281.

RODRÍGUEZ TEMIÑO, I.: "Ciencia arqueológica, patrimonio arqueológico y expolio", en AA.VV.: La protección del patrimonio arqueológico contra el expolio, Sevilla, 2002, pp. 9-33.

"El expolio del patrimonio: la arqueología herida", en AA.VV.: Actas del simposio internacional "Del Ayer 
para el Mañana. Medidas de Protección del Patrimonio" (Ávila, 2003), Valladolid, 2004, pp. 303-349.

“Coleccionismo y expolio arqueológico: los comienzos de una relación problemática", en Cuadernos de prehistoria y arqueología de la Universidad de Granada, núm. 25, 2015, pp. 211-256.

ROLDÁN BARBERO, H.: El delito de malversación, Sevilla, 1996. ROMA VALDÉS, A.: "Las excavaciones ilegales y la protección penal del patrimonio arqueológico", en Revista de Derecho Ambiental, núm. 17, 1996, pp. 59-72.

“La protección penal del patrimonio arqueológico", en AA.VV.: Estudios Jurídicos. Ministerio Fiscal. Vol. VIII, Madrid, 1998.

“El expolio del patrimonio arqueológico español", en $\mathrm{Pa}$ trimonio Cultural y Derecho, núm. 6, 2002, pp. 127-147.

La aplicación de los delitos sobre el patrimonio cultural, Granada, 2008.

"La valoración de los daños arqueológicos y la justicia cautelar en el proceso penal", en PH: Boletín del Instituto Andaluz del Patrimonio Histórico, núm. 82, 2012, pp. 71-74. https://doi.org/10.33349/2012.82.3307

"Mercado de arte y antigüedades y prevención delictiva", en Cuadernos de prehistoria y arqueología de la Universidad de Granada, núm. 25, 2015, pp. 145-165.

"La estafa agravada por el valor cultural del objeto y la falsificación de obras de arte y antigüedades", en La Ley Penal, núm. 116, 2015.

"La protección penal frente al expolio arqueológico", en YÁÑEZ VEGA, A./ RODRÍGUEZ TEMIÑO, I./ ALMANSA SÁNCHZ, J. (Dirs.): El expoliar se va a acabar. Uso de detectores de metales y arqueología: sanciones administrativas y penales, Valencia, 2018, pp. 511-532.

ROMEO MARUGÁN, F., y otros: "Un nuevo sistema para la valoración económica de los daños en yacimientos arqueológicos expoliados", en Patrimonio Cultural y Derecho, núm. 21, 2017, pp. 231-267. 
ROMERO ESCABIAS DE CARBAJAL, J. A.: "Problemática jurídico-penal de la Ley de Contrabando de 1995", en SORIANO SORIANO, J. R. (Dir.): Delitos contra la salud pública y contrabando, Madrid, 2000, pp. 287-318.

RUFINO RUS, J.: "La protección del patrimonio arqueológico en el Código Penal. Deficiencias y propuestas para una reforma de las leyes sustantivas y procesales", en PH: Boletín del Instituto Andaluz del Patrimonio Histórico, núm. 82, 2012, pp. 54-70. https://doi.org/10.33349/2012.82.3306

"La tutela del patrimonio arqueológico en el Código penal", en YÁÑEZ VEGA, A./ RODRÍGUEZ TEMIÑO, I./ ALMANSA SÁNCHZ, J. (Dirs.): El expoliar se va a acabar. Uso de detectores de metales y arqueología: sanciones administrativas y penales, Valencia, 2018, pp. 467-509.

RUIZ VADILLO, E.: "La punición de los delitos de robo con fuerza en las cosas, hurto y estafa en la reforma parcial del Código Penal de 25 de junio de 1983. Las circunstancias de agravación específicas", en Estudios Penales y Criminológicos, Vol. VII, 1984, pp. 323-394.

SALINERO ALONSO, C.: La protección del patrimonio histórico en el Código penal de 1995, Barcelona, 1997.

SILVA CASTAÑO, M. L.: “Artículo 253”, en COBO DEL ROSAL, M. (Dir.): Comentarios al Código penal. Tomo VIII. Delitos contra el patrimonio y contra el orden socioeconómico (Artículos 234 a 272), Madrid, 1999, pp. 461-475.

SORIANO SORIANO, J. R.: Las agravantes especificas comunes al robo y hurto, Valencia, 1993.

SOUTO GARCÍA, E. M.: Los delitos de hurto y robo, Valencia, 2017.

TASENDE CALVO, J. J.: "Los hurtos cualificados", en TASENDE CALVO, J. J. (Dir.): Delitos contra el patrimonio. Delitos de apoderamiento, Madrid, 2004, pp. 11-54. SUÁREZ LÓPEZ, J. M.: "Artículo 323", en GÓMEZ TOMILLO, M. (Dir.): Comentarios prácticos al Código Penal. Tomo IV, Cizur Menor, 2015, pp. 85-89.

TERREROS ANDRÉU, C.: "El expolio de Patrimonio Cultural: problemas de conceptualización jurídica", en Revis- 
ta Electrónica de Patrimonio Histórico, núm. 14, junio 2014, pp. 67-97.

VALLE MUÑIZ, J. M.,/ QUINTERO OLIVARES, G.: "De las defraudaciones", en QUINTERO OLIVARES, G. (Dir.): $\mathrm{Co}-$ mentarios al Código Penal. Tomo II. Parte Especial (Artículos 138 a 318), $5^{\text {a }}$ ed. Cizur Menor, 2008, pp. 703-771.

VÁZQUEZ IRUZUBIETA, C.: Leyes complementarias del Código Penal. Doctrina y jurisprudencia, Madrid, 2011.

VERCHER NOGUERA, A.: "El expolio de bienes de patrimonio histórico o la descontextualización penal del entorno arqueológico", en Diario La Ley, núm. 9151, 5 de marzo de 2018, pp. 1-9.

VIADA Y VILASECA, S.: Código Penal reformado de 1870. Tomo II, $4^{\mathrm{a}}$ ed. Madrid, 1890.

VIVES ANTÓN, T. S./ GONZÁLEZ CUSSAC, J. L.: "Delitos contra el patrimonio y el orden socioeconómico (III)", en VIVES ANTÓN, T. S., y otros: Derecho Penal. Parte Especial, $3^{\mathrm{a}}$ ed. Valencia, 2010, pp. 381-389.

VIVES ANTÓN, T. S., y otros: Derecho Penal. Parte Especial, $6^{a}$ ed. Valencia, 2019.

YÁÑEZ VEGA, A.: "Estudio sobre la Ley de Excavaciones y Antigüedades de 1911 y el Reglamento para su aplicación de 1912", en MORA RODRÍGUEZ, G./ DÍAZ-ANDREU, M. (Eds.): La cristalización del pasado: génesis $y$ desarrollo del marco institucional de la arqueología en España, Málaga, 1997, pp. 423-430.

“Actividades ilícitas contra el patrimonio arqueológico. Sistemas punitivos penal y administrativo", en Cuadernos de prehistoria y arqueología de la Universidad de Granada, núm. 25, 2015, pp. 13-30.

_Patrimonio arqueológico y derecho sancionador, Valencia, 2018

YÁÑEZ VEGA, A./ RODRÍGUEZ TEMIÑO, I./ ALMANSA SÁNCHEZ, J. (Dirs.): El expoliar se va a acabar. Uso de detectores de metales y arqueología: sanciones administrativas y penales, Valencia, 2018. 